\title{
SZUBURBANIZÁCIÓ ÉS TÁRSADALOM ${ }^{\mathbf{1}}$
}

(Suburbanisation and Society)

\section{CSANÁDI GÁBOR - CSIZMADY ADRIENNE}

Kulcsszavak:

szuburbanizáció Budapest agglomeráció szegregáció

A Budapest és agglomerációjának helyzete jó példája annak, hogy a politikai-hatalmi struktúra változása hogyan hat a társadalmi viszonyokra. Az elmúlt néhány év alatt a két terület között - a korábbinál sokkal szorosabb kapcsolat és kölcsönhatás épült ki. Mindezek a változások indokolttá teszik, hogy azt vizsgáljuk meg, hogy a városi társadalom térbeli dimenziói hogyan értelmezhetöek akkor, ha nem egyszerüen a fóváros közigazgatási határainak keretei között vizsgálódunk, hanem vizsgálati egységünknek a fơvárost és agglomerációját tekintjük. A tanulmány elsö kérdése az, hogy a föváros és agglomerációja területén belül hogyan értelmezhetőek a társadalmi folyamatok térbeli dimenziói. Más szóval, azt vizsgáljuk, hogy a magas és alacsony státusú rétegek térbeli elkülönülése, szegregációja milyen mértékben lép át a településhatárokon, és a szegénység koncentrálódásának kockázatai milyen mintákat öltenek fel egy ilyen léptékü vizsgálat során.

A modern városok térbeli-társadalmi szerkezetének és a változás mintáinak vizsgálata a városszociológia egyik alapvető kutatási iránya. Az irodalomban két fó irányvonal feszül egymásnak, az „ecological” és a „historical”. Az első szerint a változás lényegében hasonló modell szerint megy végbe a világ különböző részein. A városfejlődés mozgatója a gazdasági fejlettség (a társadalmi-politikai tényezőknek csak módosító szerepe van), így minden város esetében ugyanazok a szakaszok követik egymást, csak bizonyos fáziskéséssel. A másik irányvonal szerint viszont hasonló gazdasági fejlettségi szintek mellett is eltérő fejlődési utak figyelhetőek meg. Vagyis a gazdasági fejlettség mellett - gyakran még annál erősebben is érvényesülnek olyan meghatározó történeti-társadalmi tényezők, amelyek a városok fejlődésének eltérő típusait hozzák létre (Szelényi 1996).

A hetvenes-nyolcvanas évek komparatív városszociológiai kutatásainak középpontjában a fenti probléma specifikus esete, a kapitalista és szocialista városok fejlődésének összehasonlítása került. Az „ecological” irányzat követői a szocialista országok és a tőkés országok városfejlődése között nem láttak lényeges eltérést, csak időbeli csúszást, amennyiben az előbbiek gazdasága gyengébb, mint az utóbbiaké; ez magyarázza a városaik között lévő különbségeket is. Enyedi György szerint például a magyar regionális fejlődés sem más, mint az általános európai fejlődés egyik alfaja, nem tekinthető lényegében eltérőnek attól, amit nyugaton megfigyelhetünk (Enyedi 1996). A „historical” irányzathoz tartozó szociológusok szerint viszont a közép-kelet-európai városok fejlődése jelentősen különbözik a nyugateurópai, illetve amerikai városok fejlődésétől, habár bizonyos hasonlóságok még így is fellelhetőek. A szocialista országok városai ugyanis azért jártak be eltérő fejlődési utat, mert a hasonló gazdasági fejlettségü kapitalista országokhoz képest eltérő térbeli-társadalmi szerkezettel rendelkeztek. A fejlődést alapvetően a piaci 
viszonyok hiánya és az állami redisztribúció alakította. A társadalmi egyenlőtlenségek szerkezetének újratermelődése, a hatalmi viszonyok struktúrájának és müködési módjának eltérő volta miatt itt még az első pillantásra hasonlónak látszó jelenségek is más társadalmi jelentéssel bírtak (Welawowicz 1992; Ladányi-Szelényi 1997b; Tosics e. a. 1998).

A volt szocialista országokban a rendszerváltás érdekes - szinte kísérletinek is tekinthető - helyzetet teremtett a fenti vita számára. Most megvizsgálhatóvá vált, hogy a hatalmi-társadalmi viszonyok megváltozásával a városi társadalmi folyamatok is megváltoznak-e. Elemezhetővé váltak azoknak a különbségeknek a hatásai is, amelyek az egyes országokban a rendszerváltás történeti körülményeiben voltak megfigyelhetőek. Sok jel mutat arra, hogy a szocialista „örökség”, az átalakulás eltérő modelljei - és persze az egyes országok gazdaságának eltérő teherbírása, fejlesztésük jellegzetes útjai - olyan erősen befolyásolják a városfejlődést, hogy új - a nyugat-európaitól vagy az amerikaitól eltérő - modellek kidolgozása válik szükségessé. Tehát miközben egyáltalán nem beszélhetünk egy univerzális városfejlődés modellről, melynek csak különböző fázisaiban „tartanak” az egyes országok városai, nyitott kérdés az is, hogy miként kell magyarázni a különböző modell alapján fejlődő városok hasonló jelenségeit. A nyugat-európai és észak-amerikai városokhoz hasonlóan például itt is megindult a belső városrészek slumosodása, illetve a szuburbanizáció. A fővárosi népesség kiköltözése azonban nem tekinthető egyszerủen a nyugati értelemben vett szuburbanizációnak. Itt ugyanis nem csak a középosztály - főváros körüli településekre történő - kiköltözését figyelhetjük meg, hanem az alacsonyabb státusúak infrastrukturálisan fejletlen településre költözését is. Ezek azok, akik a szocializmus alatt a második gazdasági munkájuk eredményeként jó lakáskörülmények közé jutottak, ám a rendszerváltás után csapdába kerültek, melyből a kitörést a költözéstöl remélték (Ladányi-Szelényi 1997a).

Jelen tanulmány a vita fentebb említett aspektusát igyekszik Budapest és agglomerációjának példáján kissé világosabbá tenni. Azt próbáljuk meg bemutatni, hogy milyen tényezők azok, amelyek a kilencvenes években a főváros és környezetének kapcsolatát meghatározták. A mellett fogunk érvelni, hogy a jellegzetes társadalmi folyamatok alapvetően meghatározták a térbeni mobilitási folyamatokat is, ezek sajátosságait is. Ugyanakkor a munka bizonyos értelemben a korábbi kutatások folytatásának is tekinthető. Míg a főváros térbeni-társadalmi szerkezetének változásait korábbi kutatásainkban úgy vizsgáltuk, hogy figyelmen kívül hagytuk a főváros és agglomerációja között lévő kapcsolatot (Csanádi-Ladányi 1992), addig a rendszerváltás után már adekvátabbnak látszik a kettő együttes vizsgálata. Az elmúlt néhány év alatt ugyanis a két terület között - a korábbinál - sokkal szoros kapcsolat és kölcsönhatás épült ki. Mindezek a változások indokolttá teszik azt, hogy korábbi kutatásainkat ilyen vonatkozásban is kiterjesszük, és azt vizsgáljuk meg, hogy a városi társadalom térbeli dimenziói hogyan értelmezhetőek akkor, ha a problémát nem egyszerúen a föváros közigazgatási határainak keretei között vizsgáljuk, hanem vizsgálati egységünknek a fővárost és agglomerációját tekintjük. A város határain belül zajló területi-társadalmi folyamatok megértése ugyanis egyre nehezebb a 
nélkül, hogy a tágabb környezetben zajló tendenciákat is figyelembe vennénk. Ezért tanulmányuk első kérdése az, hogy a főváros és agglomerációja területén belül hogyan értelmezhetőek a társadalmi folyamatok térbeli dimenziói. Más szóval, azt kívánjuk megvizsgálni, hogy a magas és alacsony státusú rétegek térbeli elkülönülése, szegregációja milyen mértékben lép át a település-határokon, és a szegénység koncentrálódásának kockázatai milyen mintákat öltenek fel egy ilyen léptékü vizsgálat során.

\section{A népesség számának változása, térbeli mobilitási irányok}

A jelenleg rendelkezésre álló elemzések - a dolog jellegéből adódóan - elsősorban a különböző területeken bekövetkezett népességszám változás vizsgálatát végezték el$^{2}$. A témával foglalkozó szerzők tanulmányukban az 1990 és 1997 közötti 150 ezer fös fövárosi népességcsökkenést két fö tényezőnek tulajdonították. Az egyik a természetes fogyás, melynek nyomán a népesség 85500 fővel lett kevesebb, a másik pedig a kifelé irányuló mobilitás, mely számlájára a fennmaradó 64500 fó írható (Beluszky 1999; Dövényi-Kovács 1999). A népszámlálás előzetes adatai szerint a népesség számának csökkenése a kilencvenes évek végén is tovább folytatódott. Míg ennek hatására a főváros lakossága 1775203 före csökkent (ami az 1990-hez képest 12\%-os csökkenést jelent), addig az agglomeráció népessége 18\%-kal növekedett (ezen belül is a községek népességszámának növekedése volt a jelentősebb, 21\%). Feltételezhető, hogy az agglomerációs népességnövekedés forrása jelentős mértékben a föváros népességcsökkenése volt.

\section{TÁBLÁZAT}

A lakónépesség számának alakulása Budapesten és az agglomerációban 1990-2001 (Population Change in Budapest and Its Agglomeration, 1990-2001)

\begin{tabular}{lccc}
\hline & \multicolumn{2}{c}{ A lakónépesség száma (fö) } & 2001 évi népesség az \\
\cline { 2 - 3 } & 1990 & 2001 & 880 -es százalékában \\
\hline Budapest & 2016774 & 1775203 & 88 \\
Agglomeráció városai & 277153 & 321334 & 116 \\
$\begin{array}{l}\text { 2000-ben } \\
\text { Agglomeráció községei }\end{array}$ & 289708 & 350753 & 121 \\
2000-ben & 566861 & 672087 & 118 \\
Agglomerációs övezet & 2583635 & 2447290 & 95 \\
\hline \hline Budapest + agglomeráció & & & \\
\hline
\end{tabular}

Forrás: KSH, 1990, 2001.

Beluszky Pál a főváros elhagyásának motivációi között az esetek jelentős részében valamely szuburbanizációs település által - vélten vagy valósan - biztosított kedvezőbb lakás- és életkörülmények szerepelését tételezték fel. Kutatásaik szerint az ilyen típusú népességveszteség főleg a belső kerületeket sújtotta, míg a külső kerületek inkább népességnövekedést tapasztaltak (Beluszky 1999). A 2001-es népszámlálás kerületsoros adatai azonban ezt a feltételezést csak részben igazolták. A belső kerületek népessége - kisebb-nagyobb mértékben - valóban csökkenő ten- 
denciát mutatott. 1990-hez képest az V. kerület vesztesége volt a legmagasabb, ugyanis népessége egyharmadával csökkent. Az I., VI. és VII. kerület esetében a csökkenés egynegyed körüli, a IX. és XII. kerület esetében pedig egyötöd, a VIII. kerület népessége viszont csak egytizeddel csökkent. A külső kerületekröl azonban nem állíthatjuk egyértelmüen, hogy népességük növekedett volna. Csak három olyan kerület van, ahol a népesség jelentősebben nőtt: XVII. (8\%), XXIII (10\%) és XVI. kerület (2\%), a többi kerület esetében kisebb-nagyobb (1-17\%) csökkenést tapasztalunk.

\section{TÁBLÁZAT}

A fóvárosi kerületek népességszámának változása 1990-2001 (Population Change in the Districts of Budapest, 1990-2001)

\begin{tabular}{|c|c|c|c|c|c|c|c|}
\hline \multirow{2}{*}{ Kerület } & \multicolumn{2}{|c|}{$\begin{array}{c}\text { A lakónépesség } \\
\text { száma }\end{array}$} & \multirow{2}{*}{$\begin{array}{l}\text { 2001. évi } \\
\text { népesség } \\
\text { az 1990-es } \\
\text { százaléká- } \\
\text { ban }\end{array}$} & \multirow{2}{*}{ Kerület } & \multicolumn{2}{|c|}{$\begin{array}{c}\text { A lakónépesség } \\
\text { száma }\end{array}$} & \multirow{2}{*}{$\begin{array}{l}2001 \text {.évi } \\
\text { népesség } \\
\text { az 1990-es } \\
\text { százaléká- } \\
\text { ban }\end{array}$} \\
\hline & 1990 & 2001 & & & 1990 & 2001 & \\
\hline I. & 34778 & 25917 & 75 & XIII. & 131143 & 114357 & 87 \\
\hline II. & 102758 & 92611 & 90 & XIV. & 143501 & 123514 & 86 \\
\hline III. & 149028 & 129699 & 87 & $\mathrm{XV}$. & 95593 & 85236 & 89 \\
\hline IV. & 108453 & 103196 & 95 & XVI. & 69410 & 71031 & 102 \\
\hline V. & 43937 & 28952 & 66 & XVII. & 72317 & 79991 & 111 \\
\hline VI. & 59477 & 44141 & 74 & XVIII. & 97700 & 96357 & 99 \\
\hline VII. & 82868 & 64141 & 77 & XIX. & 72838 & 63774 & 88 \\
\hline VIII. & 92386 & 81791 & 89 & XX. & 71685 & 65297 & 91 \\
\hline IX. & 78422 & 62999 & 80 & XXI. & 90197 & 80986 & 90 \\
\hline $\mathrm{X}$ & 96843 & 80553 & 83 & XXII. & 53282 & 52550 & 99 \\
\hline XI. & 174509 & 144445 & 83 & XXIII. & 19185 & 20701 & 108 \\
\hline \multirow[t]{2}{*}{ XII. } & 76495 & 61415 & 80 & & & & \\
\hline & & & & $\begin{array}{l}\text { Buda- } \\
\text { pest } \\
\text { össz. }\end{array}$ & 2016774 & 1775203 & 88 \\
\hline
\end{tabular}

Forrás: KSH 1990, 2001.

A változás okát két fő tényezőben kell keresni, az egyik a természetes szaporodás, a másik az oda- és elvándorlás egyenlege. Az I. és II. kerület esetében a népességveszteségért a fenti két tényező fele-fele arányban felelős. A VII., VIII., XIII. és XIV. kerületek népességfogyása mögött döntően a természetes fogyás, míg a III., V., IX., X. és XII. kerület esetében az elköltözés áll. Ezzel szemben a IV., XVI., XVII., XXII. és XXIII. kerületek esetében a változás nem tulajdonítható egy tényezőnek. Itt ugyanis a természetes fogyással azonos, vagy azt meghaladó mértékü vándorlás általi nyereség a népességszám emelkedéséhez, vagy legalábbis stagnálásához vezetett (Tomay 2002). Az utóbbi tíz évben tehát a népesség változásánál a költözések egyenlegének a korábbi években tapasztaltnál jelentősebb szerepe volt. Ezért Beluszky Pál hipotézisét nem csupán a vándorlási nyereség, illetve veszteség 
területén érdemes pontosítani, hanem a vándorlást kiváltó okok területén is. Arra szeretnénk választ adni, hogy mi okozza bizonyos területekről a jelentősebb, másokról a mérsékeltebb elköltözést. Megvizsgálandónak tartjuk, hogy a különböző státusú csoportok milyen mértékben vesznek részt e költözési folyamatban és milyen irányokba mozdulnak el. ${ }^{3}$ Továbbá, hogy mik azok a legfontosabb ható erők, melyek a térbeli mobilitási folyamatokat - a kilencvenes években - meghatározták.

Hipotézisünk szerint a rendszerváltás után megindult nagy arányú mobilitásban a bérlakások privatizációját jelentős motivációs tényezőként kell számon tartani. Mivel az önkormányzat bérlakás-állománya nem csak a belső kerületekre összpontosult, ezért belátható, hogy a privatizációs hatás nem csak a belső kerületek, hanem a külső kerületek népességének csökkenéséhez is hozzájárulhatott. A lakásprivatizáció többféle hatást gyakorolt az érdekeltek különböző csoportjaira. Egyebek között jelentősen megnövelte a költözés felé hajtó lehetőségeket, illetve szorító kényszereket is. Modellszerüen azt mondhatjuk, hogy a lakásprivatizáció következtében azok, akik kedvező ökológiai pozícióban lévő jó állapotú lakást vehettek meg, és maguk is rendelkeztek megfelelő saját illetve családi tőkével, a budapesti agglomeráció magas státusú részeire költöztek. Azok a családok, akik a főváros kevésbé előnyös helyzetű környékén vehették meg korábbi bérlakásukat - és így az addicionális tőke viszonylag szerényebb volt -, jellemzően a keleti-délkeleti agglomerációs övezet felé, illetve a fővárostól valamivel távolabb eső - de még mindig az agglomerációba tartozó - településekre költöztek. Azok a csoportok pedig, amelyek esetében a bérlakás-privatizáció következményei bizonyos értelemben a terhek megnövekedését jelentették, a fövárostól távol levő (már nem az agglomerációhoz tartozó) települések felé mozdultak el. Az ö esetükben a költözés nem annyira a lakáshelyzet, illetve a szimbolikus társadalmi helyzet javítására szolgált, hanem az egyre kockázatosabb - díjhátralékos, eladósodást elöre vetítő - csapdahelyzetből való menekülést jelentette. Esetükben a település kiválasztásánál jelentős szerepet játszottak a családi kötelékek. Rendszerint oda költöztek vissza, ahonnan az ötveneshatvanas években a fővárosba, illetve környékére érkeztek. E családok jelentős része úgy költözött a fővárosba, hogy a tágabb család valamely ága megtartotta a vidéki lakóhelyet (különösen kelet-magyarországi településeken), ennek következtében a most visszaköltözők még rendelkeznek bizonyos ingatlan-vagyonnal, akár részben üres lakásokkal is, amelyek felújítása aránylag olcsón megoldható volt. Így a budapesti rossz állapotú lakásért kapott igen szerény összeg is alkalmas lehetett arra, hogy a család kikerüljön a lakásprivatizáció miatt előállt csapdából. Persze ez a megoldás igen kockázatos, tartóssága attól függ, hogy mennyire sikerül munkát találni ezeken a településeken, illetve, hogy a hagyományos családi network menynyire segít abban, hogy a régen elhagyott világba vissza lehessen illeszkedni.

Mivel a népszámlálás előzetes adatai sem az elköltözöttek státusz szerinti megoszlásáról, sem pedig költözésük irányáról nem tartalmaznak információt, ezért az erre vonatkozó hipotéziseinket hivatalos adatbázisokon nem tesztelhetjük. Rendelkezésünkre áll viszont egy olyan adatbázis, mely a fővárosból kiköltöző, illetve az 
agglomerációs településekre beköltöző népesség motivációit és státuszviszonyait tárja fel. ${ }^{4}$

Hipotézisünk tesztelését azzal kezdjük, hogy megvizsgáljuk, hogy mennyiben különbözik egymástól azoknak a státusa, akik a rendszerváltást követő 6-7 évben a főváros határain belül kerestek különböző okokból más lakást maguknak, azokétól, akik az agglomerációba, illetve az ország más területeire költöztek el?

\section{TÁBLÁZAT}

1990-1997 között Budapesten belül, Budapestről az agglomerációba és azon kívülre költözöttek megoszlása iskolai végzettségük szerint (\%)

(Distribution of People Migrate within Budapest, from Budapest to the Agglomeration and to other Places between 1990-1997 by Their Educational Qualification, \%)

\begin{tabular}{|c|c|c|c|c|c|}
\hline \multirow{2}{*}{ Iskolai végzettség } & $\begin{array}{l}\text { Budapes- } \\
\text { ten belül }\end{array}$ & $\begin{array}{l}\text { Agglome- } \\
\text { rációba }\end{array}$ & Máshová & \multirow{2}{*}{$\begin{array}{l}\text { Összes } \\
\text { Budapest- } \\
\text { ről elköl- } \\
\text { töző }\end{array}$} & \multirow{2}{*}{$\begin{array}{c}\text { Budapesti } \\
\text { felnőttek } \\
\text { együtt }\end{array}$} \\
\hline & & költöző & & & \\
\hline $\begin{array}{l}8 \text { általánosnál } \\
\text { kevesebb }\end{array}$ & 4,5 & 2,4 & 7,2 & 5,0 & 7,2 \\
\hline 8 általános & 14,3 & 14,0 & 29,1 & 22,1 & 19,3 \\
\hline Szakmunkásképző & 18,5 & 20,5 & 25,3 & 23,0 & 18,5 \\
\hline Érettségi & 36,7 & 34,4 & 20,7 & 27,1 & 34,5 \\
\hline Föiskola, egyetem & 25,9 & 28,7 & 17,6 & 22,8 & 20,6 \\
\hline Összesen: $100,0 \mathrm{~N}=$ & $\mathrm{N}=1896$ & $\mathrm{~N}=221$ & $\mathrm{~N}=256$ & $\mathrm{~N}=477$ & $\mathrm{~N}=10407$ \\
\hline
\end{tabular}

Forrás: A survey adataiból végzett számítások.

Annak érdekében, hogy világosabb legyen, kikből is tevődnek össze a költözők egyes csoportjai, táblánk utolsó oszlopához - amely a fővárosban lakó felnőttek iskolai végzettségi megoszlását mutatja - viszonyítjuk a különböző költözési irányok felé indult, eredetileg fővárosban lakó csoportokat. A vizsgált hét évben a diplomások aránya az agglomerációba költözöttek között volt a legmagasabb, (28,7\%) valamivel megelőzve a fővároson belül költözők 25,9\%-os arányát. Ez arra utal, hogy a budapesti magas státusúak számára a vizsgált időszakban a kialakuló magas státusú agglomerációs övezetek már egyenrangú alternatívát jelentenek a fővároson belül található megoldásokkal. Mindkét költözési pályára az a jellemzö, hogy közöttük - a fővárosi átlaghoz képest - harmadával-negyedével alacsonyabb az iskolázatlanok aránya, s így - együtt a diplomások arányának a fővárosi átlagnál magasabb voltával - azt mondhatjuk, hogy a lakásmobilitás e két viszonylag magas státusú pályája jellegzetesen eltérő szerepet tölt be az agglomeráción kívülre való költözéshez képest. Ez utóbbi esetben az iskolázatlanok aránya jóval magasabb, mint az a fövárosra általában jellemző, és a diplomások aránya pedig számottevően alatta marad a fövárosi átlagnak. Az összetétel eltérése mögött minden bizonnyal az húzódik meg, hogy nem csupán annak vagyunk tanúi, hogy a fővároson belül bekövetkező lakásmobilitási rendszert kiegészíti a - jelentős mértékben magas státusú - 
agglomerációs területre történő vándorlás, hanem annak is, hogy Budapest viszonylag elesett lakóinak egy része az ország távolabbi részeibe költözik.

\section{TÁBLÁZAT}

1990-1997 között Budapesten belül, Budapeströl az agglomerációba és azon kívül költözöttek megoszlása vagyoni helyzetük alapján (\%) ${ }^{5}$

(Distribution of People Migrate within Budapest, from Budapest to the Agglomeration and to other Places between 1990-1997 by Their Property Status, \%)

\begin{tabular}{lcccc}
\hline & $\begin{array}{c}\text { Budapesten } \\
\text { belül }\end{array}$ & $\begin{array}{c}\text { Agglomerá- } \\
\text { cióba }\end{array}$ & Máshová & $\begin{array}{c}\text { Összes Bu- } \\
\text { dapeströl } \\
\text { elköltözö }\end{array}$ \\
\cline { 2 - 5 } & & költözö & & 13,4 \\
\hline Elesett & 10,3 & 5,0 & 20,7 & 80,1 \\
Egyik sem & 75,7 & 87,0 & 74,1 & 6,5 \\
Jómódú & 14,0 & 8,1 & 5,2 & $\mathrm{~N}=477$ \\
\hline Összesen:100,0 N= & $\mathrm{N}=1896$ & $\mathrm{~N}=221$ & $\mathrm{~N}=256$ & \\
\hline
\end{tabular}

Forrás: A survey adataiból végzett számítások.

A Budapesten belül és az agglomeráció felé irányuló költözési folyamatokban érintettek, vagyoni státusuk szerint többé-kevésbé a fővárosi átlagnak megfelelő összetételúek voltak, vagyis a jómódúak aránya közel másfélszerese volt az elesettekének. A két csoport közötti jelentős eltérés viszont az, hogy az agglomerációba költözöttek között mindkét szélső csoport aránya kisebb volt, tehát a közepes helyzetűek érdekérvényesítő stratégiái között látszik lényegesebbnek ez a költözési megoldás. Ezzel szemben azok, akik az ország távolabbi vidékeire költöztek, több mint kétszer olyan gyakran voltak elesettnek tekinthetőek, mint amilyen gyakori ez a fővárosban általában, és a jómódúak aránya is csak mintegy fele a fővárosban megfigyelhetőnek. Úgy látszik tehát, hogy az agglomerációba költöző népesség jelentős része középosztálybeli, míg a távolabbi településre költözők között igen magas az alsóközép-, illetve alsó osztályokhoz tartozók aránya.

\section{TÁBLÁZAT}

1990-1997 között Budapeströl az agglomerációba és azon kivül költözöttek jelenlegi lakóhelyi státus szerinti megoszlása (\%)

(Distribution of People Migrate within Budapest, from Budapest to the Agglomeration and to other Places between 1990-1997 by Their Present Residence, \%)

\begin{tabular}{|c|c|c|}
\hline & Agglomerációba & Máshová \\
\hline & \multicolumn{2}{|c|}{ költöző } \\
\hline Szegény & 5,5 & 24,1 \\
\hline Lakótelep & 8,6 & 18,7 \\
\hline Családi ház & 69,4 & 49,4 \\
\hline Elit & 16,5 & 7,8 \\
\hline Összesen:100,0 N= & 181760 & 54746 \\
\hline
\end{tabular}

Forrás: A survey adataiból végzett számítások. 
Jellegzetesnek tekinthető az is, hogy a Budapestről különböző irányokba elköltöző népesség milyen státusú lakóövezetbe került. Az agglomerációba költözöttek között ötödannyi a szegény környékre távozottak aránya, mint azok között, akik távolabbra költöztek. Ugyanakkor az elit övezetbe irányulók aránya jelentősen meghaladja a magas státusú agglomerációs övezet lakónépességen belül megfigyelhető súlyát. Míg ugyanis az agglomeráció népességének mintegy 9\%-a lakik a magas státusú övezetben, az ide költözők között ez az arány majdnem kétszer ekkora. Ez az adat tehát más oldalról teszi hangsúlyosabbá azt a tényt, hogy az agglomeráció bizonyos körzetei egyre dinamikusabban válnak magas státusú társadalmi csoportok, míg más körzetei alacsonyabb státuszú népesség költözési cél-területeivé. Olyan hipotézist is megfogalmazhatunk, miszerint a felsőközéposztály szívesen költözik az övénél magasabb státuszú környékre, így stabilizálván, szimbolizálván saját társadalmi státuszát. Illetve fordítva, hogy a kiköltöző középosztály jelentős része nem státuszának megfelelő helyre kerül, mely mögött leginkább anyagi okot feltételezünk. A fővárosi lakás eladásával szerzett összeg magasabb státuszú környéken nem jelentené a lakáshelyzet javulását, míg alacsonyabb státuszú környéken a lakáshelyzet jelentősen javíthatóvá válik.

\section{TÁBLÁZAT}

Az 1990-1997 között Budapestről költözöttek költözési indokainak gyakoriságai a költözés iránya szerint (\%)

(Frequencies of Migration Motivation of People Moving out from Budapest between 1990-1997 by the Direction of Migration, \%)

\begin{tabular}{lccc}
\hline \multirow{2}{*}{ A költözés indoka } & $\begin{array}{c}\text { Budapesten } \\
\text { belül }\end{array}$ & $\begin{array}{c}\text { Agglomerá- } \\
\text { cióba }\end{array}$ & Máshová \\
\cline { 2 - 4 } & \multicolumn{3}{c}{ költözö } \\
\hline Túl drága volt az élet & 7,7 & 12,0 & 28,7 \\
Nem volt munkalehetőség & 3,6 & 2,6 & 10,6 \\
Drága volt a lakás fenntartása & 11,8 & 17,0 & 26,0 \\
Jobb lakásba akart költözni & 54,4 & 55,0 & 34,5 \\
Rokonok közelébe akart költözni & 16,0 & 23,2 & 43,5 \\
Jól értékesíthető bérlakás & 6,6 & 14,8 & 12,9 \\
\hline
\end{tabular}

Forrás: A survey adataiból végzett számítások.

A fővároson belül, illetve a fővárosból elköltözők költözési cél-területeinek társadalmi jelentését valamivel világosabbá teheti, ha megvizsgáljuk azt is, hogy milyen motívumokról számoltak be megkérdezettjeink akkor, amikor a költözés körülményeiről nyilatkoztak. A költözéshez vezető okokat az agglomerációval foglalkozó kutatók közül már sokan vizsgálták, mi most csak néhány ,álláspontot” és tapasztalatot emelnénk ki.

Beluszky Pál feltételezése szerint a kiköltözések egyik elsődleges indoka valamely szuburbanizációs település által - vélten vagy valósan - biztosított kedvezőbb lakás- és életkörülmények keresése volt. Ugyanígy vélekedik Tímár Judit is, aki szerint a kiköltözőket környezeti elönyök, illetve a kertes családi ház birtoklása motiválják, ezek a motivációk pedig kísértetiesen hasonlóak az amerikai szuburba- 
nizáció során tapasztaltakkal (Tímár 1999). Dövényi Zoltán 1998-as empirikus kutatásában a tipikus szuburbán indokokat (jobb lakókörnyezet, nagyobb lakás iránti igény, jó befektetés stb.) a kérdezettek 90\%-a jelölte meg (Dövényi e.a. 1998). Vizsgálatunk egyrészt alátámasztja ezeket a hipotéziseket, illetve tapasztalatokat, másrészt a kiköltözések mögött álló más természetü okokra is rávilágít. Ezeknek az okoknak a megjelenését nem önmagukban, hanem a Budapesten belül, az agglomerációba és az agglomeráción túlra költözők indokai között vizsgáljuk.

Az agglomeráción kívülre költözők alacsony státusa, és az ezzel összefüggő kényszer-költözések valószínűsége körükben lényegesen magasabb, mint azok között, akik a kilencvenes években a fövároson belül költöztek, vagy az agglomerációba vándoroltak. Erre utal, hogy a költözési indokok között az aránylag konvencionális, szuburbanizálódásra utaló 'tágasabb, jobb lakást szeretett volna' csak 34,5\%-os arányban fordul elö, míg a másik két költözési típus esetében több mint 50\%-os aránnyal találkozhatunk. Valószínüleg azonban ennél is árulkodóbb, hogy a távolabbi környékekre költöző kérdezettjeink több mint egynegyede $(28,7 \%$-a) olcsóbb környék felé kényszerült mozdulni, és közel egynegyedük (26\%) a korábbi budapesti lakást fenntarthatatlanul drágának találta. Ez különösen magas arány, ha a másik két térbeli mobilitási úttal hasonlítjuk össze - 7,7 és 12,0\%, illetve 11,8 és $17,0 \%$.

Mint korábban említettük hipotézisünk szerint a bérlakás-privatizációnak jelentős szerepe volt a térbeli mobilitás megerősödésében, és irányainak meghatározódásában. Ennek a feltevésnek igazolásához igen fontos adalék azoknak az aránya, akik a korábbi bérlakás privatizáció folyamatának valamelyik fázisában vették meg korábban tanácsi-önkormányzati lakásukat, és az így szerzett relatív piaci elönyt használták fel a költözés elősegítésére. Sok vita volt már arról, hogy kik is azok, akik ebben a folyamatban jobban jártak, és kik, akik kevésbé jártak jól. Valamint, hogy mi is lesz a társadalmi következménye Budapest viszonylag leromlott övezeteire a lakások privatizációjának. Ebben a vitában most nem szeretnénk állást foglalni, azonban a privatizáció hatásának egy részét adatainkkal demonstrálni tudjuk, még akkor is, ha mintánk méretei - és magának a felvételnek a jellege - bizonyos korlátokat állít a következtetések elé. Hipotézisünket támasztja alá, hogy a fövároson belül költözők esetében a legalacsonyabb azok aránya, akiknél ez a tényező szerepet játszott. Ehhez képest majdnem kétszer akkora a privatizációs nyereség szerepe azoknál, akik az agglomeráción kívülre költöztek, miközben az agglomerációba költözők esetében még ennél is kissé magasabb. Ha ezeket a tényeket összevetjük a fôváros és agglomerációs területe státusát mérő adatokkal, akkor már valószínüsíthető, hogy a lakásprivatizáció valóban az általunk feltételezett kettős hatást gyakorolta a térbeli társadalmi folyamatokra. Egyrészt, az elesettség határán lévő, de még bizonyos mértékü mobilitásra képes fővárosi rétegek közepesen leromlott lakásaik megvételével, illetve eladásával arra voltak képesek, hogy az ország távolabbi vidékein, és általában azok szegény környékein, alacsony színvonalú házat vegyenek maguknak. Adatainkból a kis esetszámok miatt csak sejthető, valóban elsősorban azokról az elsőgenerációs fővárosiakról van szó, akiknek az iparosítás idején vezetett útjuk a 
főváros környékére, illetve a város alacsonyabb státusú övezeteibe. A lakásprivatizáció azt tette lehetővé, hogy családjuk eredeti - és, mint látjuk, döntően ma is elesettnek tekinthető körzetben lévő - lakóhelyén az ott található szegényes bázist kiegészítve próbálkozzanak helyzetüket stabilizálni.

Mint a költözök összlakossághoz viszonyított társadalmi összetételének vizsgálatánál már jeleztük, igen fontos még egyszer aláhúzni, hogy ez az elköltöző csoport nem a fơváros leginkább elesett rétegét jelenti, hanem csak a szegénység határán lévőket. Ök még képesek voltak arra, hogy mozgósítsák a családi tőke-forrásokat, illetve éljenek a lakásprivatizáció során ehhez társuló nyereséggel, és így 'menekülési útvonalat' alakítsanak ki maguknak. A fontos jellemző éppen a relativ dinamizmus, és az a kötődés, ami a fövárosi családok e részénél a vidék meghatározott státusú övezeteihez kapcsolódik.

A másik oldalon, a magas státusú népesség egy része képes volt arra, hogy a lakásprivatizációból komparatív előnyökhöz jusson. Az agglomerációba költöző diplomások között valamivel magasabb azoknak az aránya, akik a lakásprivatizáció kedvező anyagi hatásáról számolnak be, mint az összes agglomerációba költöző lakó esetében. A lényegesebb eltérés azonban az agglomeráció egyes területeire költözött értelmiségiek helyzetében van. Az északnyugati magas státusú területre költözök között közel háromszor annyian vannak, akik ezt a tényezöt említik, mint az északkeleti területre költözők esetében tapasztalhatjuk. A tágabb, jobb lakás igen gyakori említése, illetve a környezett szennyezettség, mint költözési ok hasonlóan magas szintủ említései jól mutatják azt a már korábban is valószínűsített összefüggést, hogy ezek a csoportok együttesen képesek voltak arra, hogy többféle tőketípus mozgósításával relatív előnyeiket lakóhelyi státusukban is kifejezésre juttassák, illetve, azt még hangsúlyosabbá tegyék. Természetesen itt sem homogén csoportról van szó. Mint korábban, az egyes övezetekbe áramlók társadalmi összetételét jelző adatoknál is láttuk, a három agglomerációs övezet szimbolikus értéke sem azonos, így a magas státusú rétegeken belül is számottevő eltérések tapasztalhatók a tekintetben, hogy melyik agglomerációs területre irányul költözési trendjük.

$\mathrm{Az}$ a tendencia látszik kibontakozni, hogy a több generációs, erősebb anyagi és kulturális tőkével rendelkező, és így Budapesten belül korábban is viszonylag kedvező lakóhelyü, magas társadalmi státusú rétegek a lakásprivatizációs nyereség fokozott felhasználásával a legmagasabb státusú északnyugati agglomerációs területekre költöztek, így relatív előnyeik tovább nőttek. Azok az értelmiségi csoportok, akik viszont Budapest relatíve alacsonyabb státusú körzeteiböl indultak, a lakásprivatizáció hasznából így kevésbé voltak képesek részesülni, és gyakrabban első generációs értelmiségiek, a másik két agglomerációs terület, társadalmi státust kevésbé emelő körzetei felé mozdultak el.

Nyilvánvaló, hogy a magas és az alacsony státusú budapesti népesség költözési tipológiájának, illetve e tipológia társadalmi hatóerőkkel való összekapcsolásának csupán az első lépéseinél járunk. További vizsgálatokra van szükség ahhoz, hogy a magas és az alacsony státusú népesség térbeli mobilitásának, az ezt befolyásoló erőknek és a térbeli-társadalmi következmények rendszerének világos képét adhas- 
suk, mégis azt reméljük, hogy a fentiek is segíthetnek abban, hogy az elmúlt idöszak alapvető társadalmi-térbeli folyamatait megérthessük.

\section{A föváros és az agglomeráció belsö tagoltsága, a társadalmi helyzet és térbeli pozíció összefüggései}

A kilencvenes évek utolsó harmadára tehát a fôváros és agglomerációjának népessége az előbb leírtak alapján ,átrendeződött”. Eddig fel tudtuk vázolni a költözési irányokat, az eltérő státusú csoportok motivációit, a mögöttük álló hatóerőket. Most nézzük meg, hogy a mozgások nyomán milyen státusú népesség él a fơvárosban és agglomerációjában, és hogy milyen összefüggések vannak a térbeli pozíció és társadalmi státus között. Arra törekszünk, hogy feltárjuk a főváros és az agglomeráció belső strukturáltságát is, ezért a fővárosiak területi státusát jelző változót kiterjesztjük az agglomerációs területre is. ${ }^{6}$

A fővárost körülvevő agglomeráció társadalmi jellemzőinek vizsgálatakor nem szabad figyelmen kívül hagynunk, azt, hogy az agglomerációs övezetet - Budapesthez képest - éppen a térbeli dimenzióból adódóan kissé másképp kell megközelítenünk. Itt ugyanis a területi különbségek nem csak egy településen belül 'elrejtve', hanem települések, települések csoportjai között is jelentkeznek, ráadásul meglehetősen nagy területen szétszórva. Ennek következtében a megkérdezettek területi státusát - a lakóhely közvetlen környezetének survey-ben is mért jellegzetességei mellett - egyrészt az befolyásolja, hogy az adott település földrajzilag hol helyezkedik el az agglomerációban, másrészt az, hogy milyen státusú maga a vizsgált település. Mivel azonban a korlátozott mintanagyság bizonyos kompromisszumokra kényszerít, ezért a Budapestet és agglomerációját is magába foglaló sokaság területi státusát jellemző változót az agglomerációs övezetben lakókra elsősorban a közvetlen környezet státusának jellemzöiből alakítottuk ki, és az agglomerációs övezet egyes részeinek eltérő vonásaira az elemzés során térünk ki.

A területi státus-különbségeket vizsgálva azt találtuk, hogy, a főváros magas státusú övezetei - ahol a megkérdezettek ötödénél is kevesebb az alapfokú, vagy annál is alacsonyabb végzettségüek aránya - meglehetősen hasonlóak az agglomeráció magas státusú övezeteihez. Ennek ellenére érdemes közelebbről is megvizsgálni a közöttük meglévő kisebb különbséget, mely két jelentős súlyú tényezőre vezethető vissza: egyrészt a diplomások aránya magasabb a fővárosban, másrészt pedig - és valószínűleg ez a lényegesebb eltérés - a szakmunkás végzettségűek súlya az agglomerációban másfélszerese annak, mint amit a fövárosi elit övezetben megfigyelhettünk. Első megközelítésben úgy látszik tehát, hogy az agglomeráció magas státusú övezetei heterogénebb társadalmi összetételüek, vagyis magasabb státusú, konszolidált anyagi helyzetü kvalifikált, vállalkozó réteg számára is jelentős arányban jelentenek lakóhelyet. Tehát ebből a szempontból (sem) tekinthető a budapesti agglomeráció egységesnek 


\section{TÁBLÁZAT}

A megkérdezettek legmagasabb iskolai végzettségének eloszlása a föváros és agglomerációjának különbözö státusú övezeteiben (\%)

(Distribution of Highest Educational Qualification of Questioned Persons in the Different Status Zones of the Capital and Its Agglomeration, \%)

\begin{tabular}{|c|c|c|c|c|c|c|}
\hline & $\begin{array}{c}8 \text { ált. } \\
\text { kevesebb }\end{array}$ & $\begin{array}{c}8 \text { általá- } \\
\text { nos }\end{array}$ & $\begin{array}{c}\text { Szak- } \\
\text { munkás- } \\
\text { képző }\end{array}$ & Érettségi & Felsőfok & \multirow[t]{2}{*}{$\begin{array}{c}\text { Összes: } \\
100 \%\end{array}$} \\
\hline & \multicolumn{5}{|c|}{$\%$} & \\
\hline \multicolumn{7}{|l|}{ Budapest } \\
\hline Társasház, villa & 4,5 & 13,2 & 11,0 & 37,5 & 33,8 & $\mathrm{~N}=1580$ \\
\hline Családi ház 1. & 6,0 & 15,6 & 17,0 & 35,6 & 25,7 & $\mathrm{~N}=760$ \\
\hline Családi ház 2. & 10,3 & 21,3 & 21,6 & 34,6 & 12,1 & $\mathrm{~N}=1342$ \\
\hline Lakótelep 1. & 1,6 & 10,8 & 17,3 & 41,4 & 28,8 & $\mathrm{~N}=885$ \\
\hline Lakótelep 2. & 4,5 & 16,7 & 19,0 & 37,7 & 22,1 & $\mathrm{~N}=1219$ \\
\hline Lakótelep 3. & 6,2 & 23,5 & 19,3 & 36,5 & 14,5 & $\mathrm{~N}=1643$ \\
\hline Bérház 1. & 10,1 & 19,8 & 15,5 & 32,4 & 22,2 & $\mathrm{~N}=1270$ \\
\hline Bérház 2. & 10,6 & 23,8 & 25,9 & 26,3 & 13,4 & $\mathrm{~N}=655$ \\
\hline Bérház 3. & 10,1 & 25,9 & 26,7 & 26,6 & 10,8 & $\mathrm{~N}=626$ \\
\hline Szükséglak, egyéb & 14,9 & 32,7 & 21,7 & 19,6 & 11,0 & $\mathrm{~N}=427$ \\
\hline Budapest összesen & 7,2 & 19,3 & 18,5 & 34,5 & 20,6 & $\mathrm{~N}=10407$ \\
\hline \multicolumn{7}{|l|}{ Agglomeráció } \\
\hline Aggl.szegény & 23,1 & 38,5 & 19,2 & 12,9 & 6,2 & $\mathrm{~N}=163$ \\
\hline Aggl. Lakótelep & 1,6 & 20,9 & 25,7 & 34,0 & 17,7 & $\mathrm{~N}=307$ \\
\hline Aggl.családiház & 13,4 & 27,2 & 28,0 & 22,2 & 9,1 & $\mathrm{~N}=1870$ \\
\hline Aggl.elit & 1,8 & 18,8 & 15,5 & 39,0 & 24,9 & $\mathrm{~N}=175$ \\
\hline Aggl.összesen & 11,7 & 26,6 & 26,4 & 24,4 & 11,0 & $\mathrm{~N}=2556$ \\
\hline $\begin{array}{l}\text { Budapest+ aggl. } \\
\text { összesen }\end{array}$ & 8,1 & 20,7 & 20,0 & 32,5 & 18,7 & $\mathrm{~N}=12923$ \\
\hline
\end{tabular}

Forrás: A survey adataiból végzett számítások.

Elemzésünk még tovább finomítása érdekében az agglomerációt három részre osztottuk. Megkülönböztetjük a fővárostól délre elterülő részt (első agglomerációs terület): ide tartoznak a Duna keleti oldalán a Gyál-Gyömrö környékén fekvő települések, a Csepel szigeten fekvő települések (pl. Tököl, Szigetszentmiklós) és a budai oldalon az Érdig nyúló körzet települései. A második agglomerációs terület a Duna bal partján az előbbitől északra elterülö, Gödöllő környékétől Vácig terjedő körzetet jelenti, míg a harmadik részt a budai oldal Törökbálinttól északra fekvö települései jelentik.

A fent nagy vonalakban, az egész agglomeráció területére versus a fövárosra megvizsgált összefüggéseket, most már a három részre osztott agglomerációs terület segítségével finomítjuk tovább. A területi-lakóhelyi státus és az iskolai végzetséggel mért társadalmi státus összefüggését vizsgálva azt mondhatjuk, hogy a há- 
rom agglomerációs terület társadalmi összetétele lényegileg tér el egymástól. Az északnyugati területen az iskolázatlanok aránya egyharmaddal alacsonyabb, miközben több mint kétszer olyan magas a diplomások aránya, mint a déli területen és ez utóbbi mutató háromszor akkora, mint az északkeleti területen (8.a,b,c, táblázat).

1. ÁBRA

$A$ vizsgált terület

(The Examined Area)

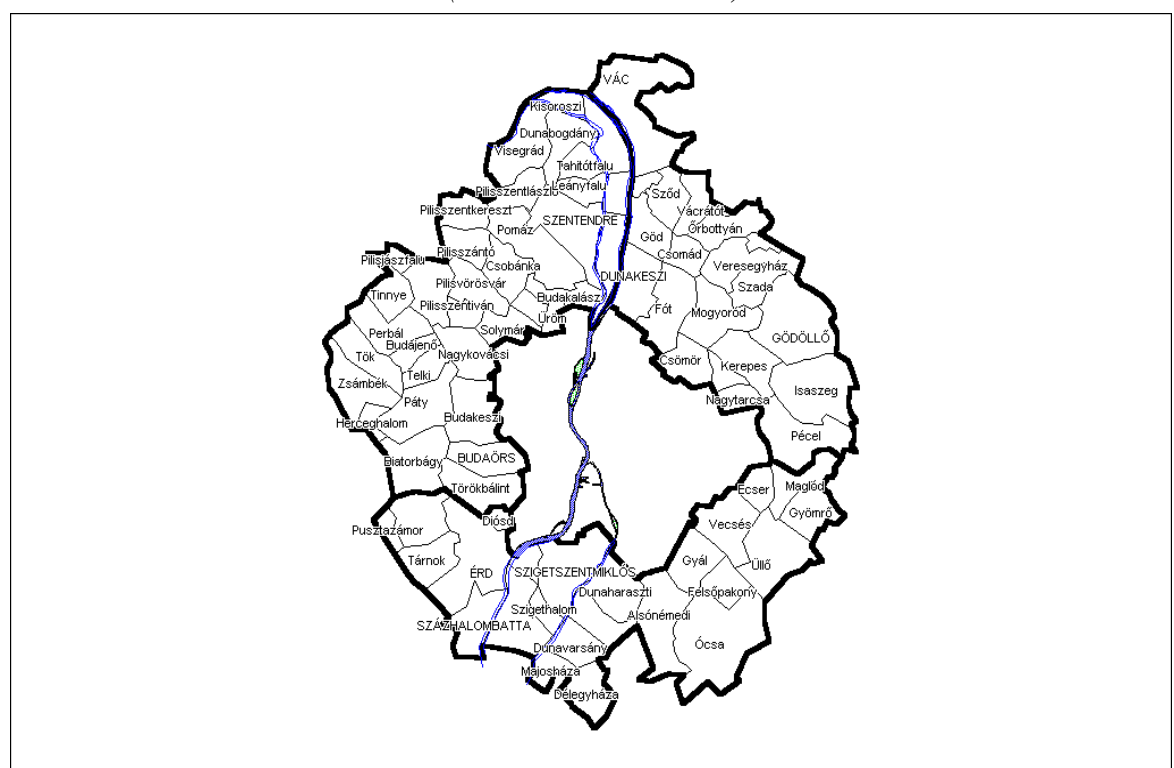

Forrás: Saját szerkesztés.

\section{TÁBLÁZAT}

A megkérdezettek legmagasabb iskolai végzettségének eloszlása az agglomeráció különbözö státusú övezetiben, területenként. (\%)

(Distribution of Highest Educational Qualification of Questioned Persons in the

Different Status Zones of the Agglomeration by Areas, \%)

a, Déli terület

\begin{tabular}{|c|c|c|c|c|c|c|}
\hline & $\begin{array}{c}8 \text { osztály } \\
\text { alatt }\end{array}$ & 8 osztály & $\begin{array}{c}\text { Szak- } \\
\text { munkás- } \\
\text { képző }\end{array}$ & Érettségi & $\begin{array}{c}\text { Főiskola, } \\
\text { egyetem }\end{array}$ & $\begin{array}{l}\text { Összesen: } \\
\mathrm{N}=100 \%\end{array}$ \\
\hline & & & $\%$ & & & \\
\hline Szegény & 23,4 & 47,9 & 20,3 & 4,3 & 4,0 & $\mathrm{~N}=45$ \\
\hline Lakótelep & 1,2 & 26,3 & 25,9 & 32,8 & 13,7 & $\mathrm{~N}=206$ \\
\hline Családi ház & 16,4 & 27,7 & 27,8 & 20,4 & 7,7 & $\mathrm{~N}=1064$ \\
\hline Elit & & 17,4 & 15,9 & 43,2 & 23,5 & $\mathrm{~N}=78$ \\
\hline Összesen & 13,4 & 27,6 & 26,6 & 23,0 & 99,4 & $\mathrm{~N}=1393$ \\
\hline
\end{tabular}




\begin{tabular}{|c|c|c|c|c|c|c|}
\hline & $\begin{array}{l}8 \text { osztály } \\
\text { alatt }\end{array}$ & 8 osztály & $\begin{array}{l}\text { Szakmun- } \\
\text { kásképző }\end{array}$ & Érettségi & $\begin{array}{l}\text { Föiskola, } \\
\text { egyetem }\end{array}$ & \multirow{2}{*}{$\begin{array}{l}\text { Összesen: } \\
\mathrm{N}=100 \%\end{array}$} \\
\hline & \multicolumn{5}{|c|}{$\%$} & \\
\hline Szegény & 20,5 & 47,1 & 24,6 & 7,7 & - & \multirow{3}{*}{$\begin{array}{l}\mathrm{N}=25 \\
- \\
\mathrm{N}=271\end{array}$} \\
\hline Lakótelep & - & - & - & - & - & \\
\hline $\begin{array}{l}\text { Családi } \\
\text { ház }\end{array}$ & 9,7 & 30,1 & 32,8 & 21,1 & 6,3 & \\
\hline Elit & 14,3 & 16,1 & 10,1 & 48,1 & 11,3 & $\mathrm{~N}=22$ \\
\hline$\overline{\overline{\text { Összesen }}}$ & 10,8 & 30,5 & 30,6 & 21,9 & 6,2 & $\mathrm{~N}=318$ \\
\hline \multicolumn{7}{|c|}{ c, Északnyugati terület } \\
\hline & $\begin{array}{c}8 \text { osztály } \\
\text { alatt }\end{array}$ & 8 osztály & $\begin{array}{l}\text { Szakmun- } \\
\text { kásképző }\end{array}$ & Érettségi & $\begin{array}{c}\text { Föiskola, } \\
\text { egyetem }\end{array}$ & \multirow{2}{*}{$\begin{array}{l}\text { Összesen: } \\
\mathrm{N}=100 \%\end{array}$} \\
\hline & \multicolumn{5}{|c|}{$\%$} & \\
\hline Szegény & 23,7 & 31,6 & 17,2 & 18,5 & 9,0 & \multirow{3}{*}{$\begin{array}{l}\mathrm{N}=93 \\
\mathrm{~N}=100 \\
\mathrm{~N}=358\end{array}$} \\
\hline Lakótelep & 2,4 & 9,9 & 25,4 & 36,4 & 25,9 & \\
\hline $\begin{array}{l}\text { Családi } \\
\text { ház }\end{array}$ & 9,5 & 20,8 & 24,4 & 28,8 & 16,4 & \\
\hline Elit & - & 21,7 & 17,1 & 32,8 & 28,4 & $\mathrm{~N}=73$ \\
\hline Összesen & 99,4 & 20,8 & 22,6 & 29,0 & 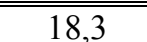 & $\mathrm{N}=625$ \\
\hline
\end{tabular}

Forrás: A survey adataiból végzett számítások.

Részletesebb finomságú adataink arra is rávilágítanak, hogy a magas státusú lakások övezete mennyire eltérő jelentésű lehet az egyes területeken. Jól lehet, a déli területen csupán $5 \%$ körül van az 'elit' lakásokban élők aránya, míg a másik két területen ez az arány 7-11\% között mozog (ami azonban még mindig alacsonyabb a fővárosban tapasztaltnál), az 'elit' területek lakóinak társadalmi összetételében jelentős különbségek mutathatók ki. E mutató mentén azt feltételeznénk, hogy a déli terület, alacsony arányú 'elit' lakóterületi népessége miatt rosszabb helyzetben van, mint a két másik terület. Azonban a lakóterület népességének részletesebb vizsgálata mást mutat.

Az északnyugati területen az 'elit' lakóövezet társadalmi összetétele közel megegyezik azzal, amit a föváros társasházas övezetében tapasztaltunk. Mindkét helyen igen magas a legalább érettségivel rendelkezők aránya (70\%). Ugyanakkor a diplomások aránya másfélszerese a területen tapasztalt átlagnak. Ennek megfelelően azt mondhatjuk, hogy ez a két magas státusú terület (főváros és északnyugati terület 'elit' lakóövezete) döntően az értelmiségi - szellemi foglalkozású, magas státusú családok körzete.

Ezzel szemben a Duna másik oldalán, az agglomeráció északkeleti részén - ahol a magas státusú lakóépületek övezete - mint jeleztük - hasonló arányú, mint a fővárosban és az északnyugati területen - már csak fele annyi a diplomások aránya, viszont majdnem másfélszer akkora az érettségizettek és az iskolázatlanok aránya, mint az északnyugati területen. Ebben az esetben tehát azt mondhatjuk, hogy a magas státusú lakások övezete az északkeleti területen alapvetően a konszolidált anyagi helyzetü közép-, alsóközép rétegeké. 
A déli terület 'elit' része lakóinak státusát tekintve valahová a két északi terület közé sorolható be, leginkább a felsőközép-, középosztály lakóhelyeként.

Jól látszik tehát, hogy az 'elit' lakóterület fizikai jellemzői, kiterjedése és lakóinak státusza együttesen határozza meg a terület tényleges státuszát, illetve, hogy 'elit' és 'elit' építésü (fizikai megjelenésü) lakónegyedek között milyen jelentős különbségek lehetnek a lakók összetételét tekintve. A lakás ugyanis egyik oldalon a magas társadalmi státusz kifejezőjeként funkcionál - északnyugati terület -, míg a másik oldalon pedig a vágyott csoport-hovatartozás megjelenítője - déli és északkeleti terület. Lakcímünk ugyanis - akarva, akaratlanul - mindig valamilyen társadalmi státuszt szimbolizál, közvetít. Igyekszünk velünk azonos, vagy kicsit magasabb társadalmi státuszúak közé költözni, akikkel azonosulni szeretnénk, hangsúlyozva helyünket a társadalomban.

\section{Társadalmi mobilitás}

A főváros és az agglomeráció társadalmának különbözőségeiről rajzolt statikus képet világosabbá teszi, ha azt is megnézzük, hogy milyen mértékben voltak társadalmilag mobilak ${ }^{7}$ azok, akik a két területen (illetve azok bizonyos részein) élnek.

A főváros és agglomerációja, illetve ez utóbbi egyes térségeiben lakók társadalmi mobilitás szerinti különbségeit vizsgálva azt találtuk, hogy a fővárosban lakók között az agglomerációban lakókhoz képest magasabb azok aránya, aki édesapjukénál magasabb iskolai végzettséget szereztek (felfelé mobilak voltak). Azonban még ennél is fontosabb az, hogy budapestiek között lényegesen kevesebb lefelé irányuló mobilitással találkoztunk. Azonban ebből az adatból még nem bizonyítható, csak sejthető, hogy - a módszertani korlátokon túl - részben az áll a jelenség mögött, hogy a fővárosból az utóbbi időszakban az agglomerációba kiköltöző csoportok viszonylag dinamikus, társadalmi értelemben is mobil réteget jelentenek. Ezt a sejtést először azzal fogjuk megerősíteni, hogy megvizsgáljuk, hogyan alakulnak a megfelelő arányszámok az agglomeráció három vizsgált területén, majd összekapcsoljuk a mobilitási és státus-adatok alapján levonható következtetéseket.

\section{TÁBLÁZAT}

A fövárosiak és az agglomerációban lakók megoszlása társadalmi mobilitás szerint (\%) (Distribution of the Inhabitants of the Capital and Its Agglomeration by Their Social Mobility, \%)

\begin{tabular}{lcccl}
\hline & $\begin{array}{c}\text { Felfelé } \\
\text { mobil }\end{array}$ & Nem mobil & Lefelé mobil & \multirow{2}{*}{$\begin{array}{c}\text { Összesen: } \\
\mathrm{N}=100 \%\end{array}$} \\
\cline { 2 - 3 } & \multicolumn{3}{c}{$\%$} & \\
\hline Budapest & 18,7 & 35,1 & 46,2 & $\mathrm{~N}=10353$ \\
Agglomeráció & 14,4 & 34,6 & 51,0 & $\mathrm{~N}=2545$ \\
$\quad$ Ebböl: & 15,1 & 34,5 & 50,5 & $\mathrm{~N}=1390$ \\
$\quad$ Déli terület & 13,3 & 37,5 & 49,2 & $\mathrm{~N}=328$ \\
$\quad$ Észak-keleti terület & 57,2 & 36,6 & 6,2 & $\mathrm{~N}=648$ \\
$\quad$ Észak-nyugati terület & 46,3 & 34,7 & 19,0 & $\mathrm{~N}=12899$ \\
\hline \hline Összesen & & &
\end{tabular}

Forrás: A survey adataiból végzett számítások. 
Ami az agglomeráció különböző státusú területeit illeti, a fenti sejtéssel összhangban lévő tendenciákat tapasztalhatunk. A déli és az északkeleti terület között az ott lakók társadalmi mobilitása szempontjából nincs lényeges különbség (közel egyhatod a felfelé mobilak és $50 \%$ a lefelé mobilak aránya). Ezzel szemben az északnyugati agglomerációs övezet sokkal dinamikusabbnak mutatkozik. Nem csak az a fontos, hogy a mobil népesség aránya majdnem negyedével magasabb - megközelíti a 60\%-ot - hanem az is, hogy a lefelé mobil népesség aránya alig nyolcada annak, amit a másik két agglomerációs területen tapasztalhattunk. Vagyis adataink arra utalnak, hogy ez a terület nem csupán magasabb státusú a másik kettőnél, hanem a fővárostól is minőségileg eltérő sajátosságokat mutat; emelkedő státusú népességgel magasabb arányban lakott, s így sok szempontból lényegesen dinamikusabb, a fejlődés társadalmi 'háttere' szempontjából sokkal kedvezőbb feltételeket biztosít.

A mobilitásról alkotott képet tovább árnyalhatjuk, ha azt is megvizsgáljuk, hogy az agglomeráció különböző területein élő, de azonos iskolai végzettségü csoportok mobilitási arányszámai milyen sajátosságokat mutatnak. A 10. táblázatban azt mutatjuk be, hogy a diplomások között milyen arányban vannak édesapjuknál magasabb iskolai végzettségüek (más szavakkal első generációs értelmiségiek), illetve azt, hogy az iskolázatlanok között milyen arányú a korábbi generációhoz képesti státus-vesztés, tehát az, amikor valaki az édesapjánál alacsonyabb iskolai végzettséggel kénytelen megelégedni.

$$
\text { 10. TÁBLÁZAT }
$$

Mobilitási arányok Budapesten és az agglomerációs területeken (Mobility Rates in Budapest and the Agglomeration, \%)

\begin{tabular}{lccc}
\hline & $\begin{array}{c}\text { Első generációs } \\
\text { értelmiségi } \\
\text { arány }\end{array}$ & $\begin{array}{c}\text { Lefelé mobil } \\
\text { arány - } 8 \text { osz- } \\
\text { tálynál keve- } \\
\text { sebbet végzett }\end{array}$ & $\begin{array}{c}\text { Lefelé mobil } \\
\text { arány - } 8 \text { osz- } \\
\text { tályt végzett }\end{array}$ \\
\cline { 2 - 4 } & \multicolumn{3}{c}{} \\
\hline Budapest & 58,4 & 24,6 & 36,2 \\
Agglomeráció együtt & 64,3 & 12,6 & 29,8 \\
$\quad$ Ebböl: & & & \\
$\quad$ Déli terület & 72,2 & 11,5 & 26,8 \\
$\quad$ Észak-keleti terület & 76,7 & 8,6 & 23,2 \\
$\quad$ Észak-nyugati terület & 52,6 & 8,5 & 23,2 \\
\hline \hline Összesen & 59,1 & 20,9 & 33,8 \\
\hline
\end{tabular}

Forrás: A survey adataiból végzett számítások.

Az árnyaltabb adatok még inkább megerősítik az agglomeráció 'dinamikusabb' voltát. Összességében ugyanis valamivel magasabb az első generációs értelmiségiek aránya, miközben a diplomások aránya csak mintegy fele akkora, mint a fóvárosban. Az agglomerációs területek közötti különbség ebben a dimenzióban is fennáll, bár egy kissé talán kevésbé mély, mint a lakóhelyi társadalmi státusz esetében. Az övezet státusára nem csak az ott élő diplomások száma van hatással, hanem ezen belül az első generációs - több generációs értelmiségiek megoszlása is. Kutatásaink 
során az az érdekes összefüggés bontakozott ki, mely szerint minél magasabb státusú egy terület, annál magasabb a több generációs értelmiségi lakók aránya azokhoz képest, akiknek szülői generációja még alacsonyabb státusú volt. Ez nem csak a fenti aránylag nagy léptékü - és ezért szükségszerüen kissé heterogén - területekre igaz, hanem akkor is érvényesült a tendencia, ha a területi státus finomabb felbontású adatait vizsgáltuk meg. Az agglomerációs terület 64,3\%-os első generációs értelmiségi arányához képest a főváros környékének legmagasabb státusú 'elit' lakóövezeteiben ez az arány csupán $40,7 \%$, míg például a családi házas övezetekben az ott lakó diplomások háromnegyede első generációs értelmiségi, és ők az agglomeráció lakótelepi körzeteiben is valamivel átlagon felüli arányban laknak. A fővároson belül a helyzet annyiban bonyolultabb, hogy itt elsősorban a három lakótelepi övezet az, ahol az első generációs értelmiségiek az átlagosnál (59,3\%) lényegesen magasabb arányban képviseltetik magukat a diplomások között. Ezeken a lakótelepeken hozzávetőleg a felsőfokú végzettségűek háromnegyede első generációs értelmiségi. Ugyanakkor a társasházas övezetben, illetve a magasabb státusú családi házas övezetben fövárosi súlyának csak mintegy négyötödét teszi ki az első generációs értelmiségiek aránya. Tehát a fővároson belül az elsőgenerációs értelmiség szívesen - esetleg más választási lehetőség hiányában - költözik lakótelepre. A lakásstruktúrán, lakáshierarchián belül a lakótelepi lakás, mintegy belépőként szolgál a későbbi magasabb státuszú lakóhelyek felé. A család felfelé mobilitási útján az iskolai végzettség emelkedésével emelkedik a lakóhelyi státusz is, az iskolai státusz stabilizálódásával - második generációs értelmiség - a lakóhelyi státusz már megfeleltetődik az iskolai státusznak, annyiban, amennyiben a család a társasházas, családi házas övezet felé mozdul el.

Az első és többedik generációs értelmiségiek arányainak különbségeit tehát a különböző státusú övezetekben több tényezővel is magyarázhatjuk. Valószínűleg az értelmiségiek belső rétegzettsége áll a háttérben, különösen a több generáción keresztül felhalmozódó anyagi és kulturális 'tőke-típusok' eloszlásában megjelenő különbségek rendszere az, aminek egyik vetülete a térbeli-társadalmi státusban megjelenő hierarchikus különbség a két értelmiségi csoport között. Ugyanakkor bizonyos jelekből az is látható, hogy aránylag bonyolult összefüggésröl van szó, amelynek elemzéséhez bizonyára jelenlegi adatbázisunk sem elégséges. Ugyanis a térbeli és az általános társadalmi státus között sem egyszerü, függvény-szerü kapcsolatban áll fenn. A mobilitási folyamatokban a térbeli státus sok esetben alapvető közvetítö tényezőként müködhet. Minden bizonnyal ez fejeződik ki abban, hogy a fővárosi lakótelepek az első generációs értelmiségiek ilyen mértékben jellegzetes lakóhelyeinek bizonyulnak. Az összefüggés sokrétegủ volta mellett szól az is, hogy a bérházas övezetben - ahol, mint láttuk, az értelmiségiek aránya alacsony, és a szegénység kockázata is számottevő - nem növekedett meg az első generációs értelmiségiek aránya. Ennek valószínüleg az az oka, hogy ez a társadalmi csoport viszonylag dinamikus, feltörekvő jellegzetességekkel rendelkezik, és ezért társadalmi státusának térbeli dimenzióban való kifejezése igen jelentős szerepet játszik. Ennek következtében a 'közismerten' leromló övezetekben lakni akkor sem látszik számukra kívánatosnak, ha - mint adataink egyébként a korlátozott esetszámok 
ellenére igazolták - maguk a lakótelepi lakások nem is feltétlenül jobbak, mint a bérházas övezet megfelelő (utcai) lakásai.

Ami pedig másik pólust, az alacsony státusú, iskolázatlan megkérdezettjeinket illeti, esetükben a legfontosabb megfigyelhetö vonás minden bizonnyal az, hogy a szülökhöz képest alacsonyabb iskolai végzettség aránylag közeli veszéllyé teheti a szegénységet, vagy legalábbis a kulturális és időnként anyagi tőke-veszteség a kockázatot jelentősen fokozhatja. Valószínüleg ez magyarázza az agglomeráció dinamikusabb népességén belül a fơvárosinál alacsonyabb lefelé mobilitási arányokat az iskolázatlanok között, illetve azt is, hogy az agglomeráció magasabb státusú északnyugati területén - a különben is alacsony arányban megtalálható iskolázatlan megkérdezett között - a lefelé történő mobilitás csak igen ritkán fordult elö.

\section{A szegénység koncentrálódásának kockázata}

A fơváros, az agglomeráció és az egyes agglomerációs területek közötti státuskülönbségek leírásakor az előbbiekben a magas státuszú területekre fókuszáltunk. Most térjünk át annak vizsgálatára, hogy milyen kockázata van a szegénység koncentrálódásának. Ismeretes, hogy az alacsony iskolai végzettség és a szegénység között bizonyos együtt járás van. Ahhoz, hogy ezt az együtt járást megerősítsük, illetve specifikáljuk, más dimenziókat is bevonunk az elemzésbe. A társadalmi helyzetet mérő mutatóval már ugyanis egyszerūen leírható, hogy a fövárosban és az agglomeráció különböző övezeteiben milyen mértékü a szegénység kockázata, illetve a relatíve jómódúak hol helyezkednek el az általunk vizsgált térben.

\section{TÁBLÁZAT}

Az anyagi státus-helyzet megoszlása a fövárosban és agglomerációjában (\%) (Distribution of the Property Status in the Capital and Its Agglomeration, \%)

\begin{tabular}{|c|c|c|c|c|}
\hline & Elesett & Egyik sem & Jómódú & \multirow{2}{*}{$\begin{array}{l}\text { Összesen } \\
\mathrm{N}=100 \%\end{array}$} \\
\hline & \multicolumn{3}{|c|}{$\%$} & \\
\hline Budapest & 9,1 & 78,1 & 12,8 & $\mathrm{~N}=10407$ \\
\hline Agglomeráció & 16,0 & 79,1 & 4,9 & $\mathrm{~N}=2556$ \\
\hline Összesen & 10,5 & 78,3 & 11,3 & $\mathrm{~N}=12963$ \\
\hline
\end{tabular}

Forrás: A survey adataiból végzett számítások.

Nagyléptékben, vagyis a főváros egésze és az agglomeráció között e mutató mentén igen jelentős az eltérés. A fővárosban a megkérdezettek csak alig több mint fele olyan, akiknél a szegénység kockázata számottevő veszélyt jelentett, viszont két és félszer akkora a jómódúak aránya. A különbséget talán még szemléletesebben fejezi ki, ha adatainkat úgy interpretáljuk, hogy azonos súlyú közepes helyzetủ megkérdezett mellett a fővárosban hozzávetőleg egyforma nagy volt az elesett és a jómódú csoport aránya, míg az agglomerációban az elesettek több mint háromszor annyian vannak, mint azok, akiket most jómódúnak tekintettünk. Az agglomerációban élők nagyobb hányadának kell tehát a szegénységgel számolnia, és jóval kisebb hányad él jómódúan, mint a fövárosban. 


\section{TÁBLÁZAT}

Az anyagi státushelyzet megoszlása iskolai végzettségenként Budapesten és az agglomerációban (\%)

(Distribution of the Property Status by Educational Qualification in Budapest and the Agglomeration, \%)

a, Budapest

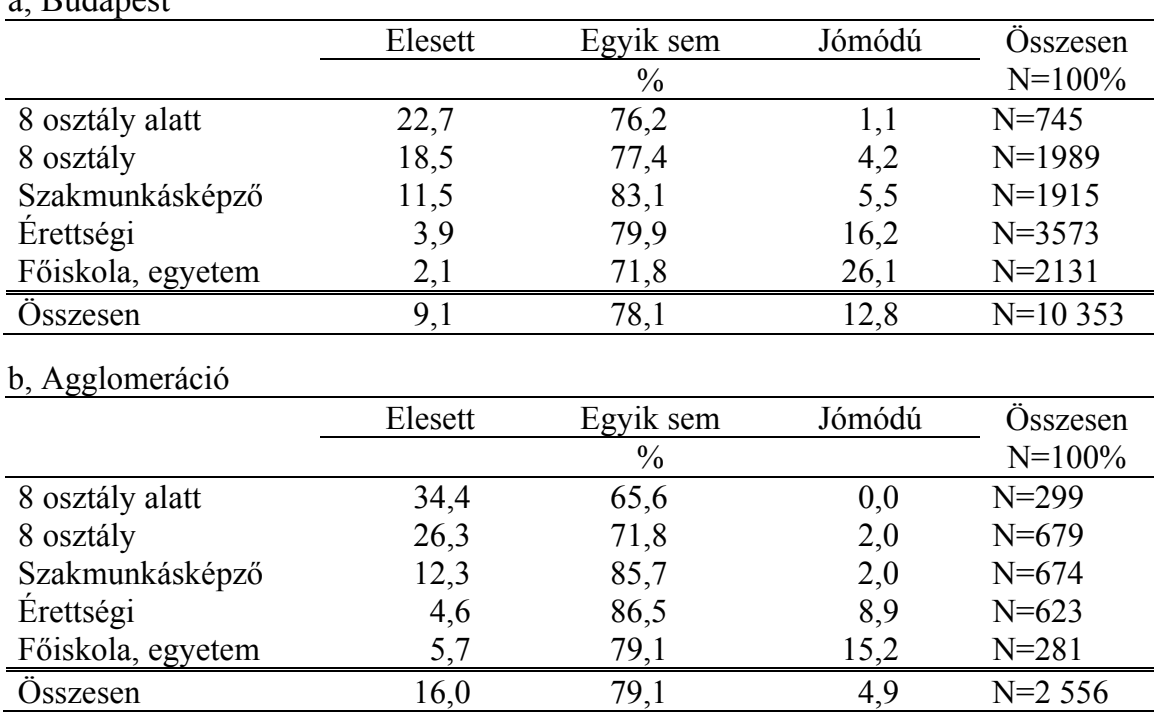

Forrás: A survey adataiból végzett számítások.

Ez az eltérés egyrészt arra - a korábban már megvilágított tényre - vezethető viszsza, hogy azok a magasabb státusú csoportok, akik között az anyagi jómód is gyakoribb, az agglomerációsnál nagyobb arányban élnek a fővárosban Így például iskolázottságot nézve elsősorban a diplomások közel kétszeres előfordulási aránya az, ami leginkább szembetünő, de az érettségizettek aránya is egyharmaddal magasabb a fővárosban, mint az agglomerációban. Természetesen ezzel együtt mozogva a kevésbé iskolázottak, illetve iskolázatlanok aránya az agglomerációban magasabb. Az iskolai státusz és elesettség mértéke közötti összefüggés azt jelzi, hogy - azonos iskolázottsági csoportokhoz tartozók - más mértékü kockázattal néznek szembe a két területen. Mást jelent például iskolázatlanként élni a fővárosban és mást az agglomerációban. A fővárosban ugyanis még a legkevésbé iskolázott rétegek is jobb helyzetben vannak, mint azok, akik az agglomerációban laknak. Az ö esetükben másfélszer olyan gyakori a szegénységi kockázat előfordulása, mint a hasonló státusú fővárosiak esetében. De az iskolázottabb társadalmi rétegeknél is rendre azt tapasztaljuk, hogy a fővárosban lakó csoportjaikon belül számottevően magasabb a jómódúak, és alacsonyabb az elesettek aránya, mint a megfelelö agglomerációban élö részsokaságban.

Összefoglalóan azt mondhatjuk, hogy a területi különbség elsősorban a két vizsgált lakóhely társadalmi összetételének eltérésein keresztül érvényesül, de - és valószínűleg ez kevésbé köztudott - az azonos státusú csoportok anyagi helyzetére 
is számottevő hatással van a fővárosi és agglomerációs lét különbözősége. Ez utóbbi - mint láttuk - elsősorban az alacsony státusú csoportok esetében érvényesül eröteljesen. Megkockáztathatjuk azt az interpretációt, hogy a megfigyelt különbségek mögött az áll, hogy a magasabb státusú csoportok jobban tudták kiegyenlíteni azokat a hátrányokat, amelyekkel a nem-budapesti lakóhely jár. Más szóval, esetükben inkább beszélhetünk arról, hogy lakóhelyük választásakor aránylag szabadon optimalizálhatják a lehetőségeket, sőt, van egy olyan csoportjuk is, amelyik éppen az agglomerációs lakóhely - persze jól körülhatárolt részének - segítségével egyszerre biztosít kedvező fizikai lakókörülményeket maga számára, és egyúttal a magas státus jelzésére is alkalmas lakóhelyet. Az alacsony státusúak esetében viszont az agglomeráció valószínüleg gyakrabban jelenti a hasonló státusúaktól való leszakadás erősödését. Mivel az agglomeráció területe nagyobb, mint a fővárosé és népessége is heterogénebb, ezért valószínűsíthető, hogy a szegénység kockázatával gyakrabban szembenéző csoportok térbeni szétszóródása is erőteljesebb. Feltételezhető, hogy az agglomeráció három területi egysége között is másképp oszlik meg. Mint azonban azt már korábban is jeleztük, a területi különbségek nem kizárólag a viszonylag nagy aggregátumokban hatnak, hanem ennél lényegesen finomabb léptékben is. Ezért most a kisebb léptékü eltéréseket vizsgáljuk meg.

\section{TÁBLÁZAT}

Az anyagi státus-helyzet megoszlása és néhány jellemzö mutató alakulása a föváros és agglomerációjának övezeteiben (\%)

(Distribution of the Property Status and Some Characteristic Indicator in the Capital and in Its Agglomeration Zones, \%)

\begin{tabular}{|c|c|c|c|c|c|}
\hline & Elesett & Egyik sem & Jómódú & \multirow{2}{*}{$\begin{array}{l}\text { Összesen } \\
\mathrm{N}=100 \%\end{array}$} & \multirow{2}{*}{$\begin{array}{l}\text { Jómódú/ } \\
\text { elesett* }\end{array}$} \\
\hline & \multicolumn{3}{|c|}{$\%$} & & \\
\hline \multicolumn{6}{|c|}{ Budapest } \\
\hline Társasház, villa & 4,2 & 74,2 & 21,6 & $\mathrm{~N}=1580$ & 5,14 \\
\hline Családi ház 1. & 5,3 & 78,1 & 16,6 & $\mathrm{~N}=760$ & 3,13 \\
\hline Családi ház 2. & 10,0 & 81,5 & 8,6 & $\mathrm{~N}=1342$ & 0,86 \\
\hline Lakótelep 1. & 3,7 & 78,3 & 18,0 & $\mathrm{~N}=885$ & 4,86 \\
\hline Lakótelep2. & 6,5 & 79,7 & 13,9 & $\mathrm{~N}=1219$ & 2,14 \\
\hline Lakótelep3. & 7,0 & 83,0 & 10,1 & $\mathrm{~N}=1643$ & 1,44 \\
\hline Bérház 1. & 11,1 & 76,6 & 12,2 & $\mathrm{~N}=1270$ & 1,09 \\
\hline Bérház 2. & 16,0 & 76,6 & 7,3 & $\mathrm{~N}=655$ & 0,45 \\
\hline Bérház 3. & 19,0 & 74,8 & 6,2 & $\mathrm{~N}=626$ & 0,32 \\
\hline Szükség és egyéb lakás & 27,3 & 68,8 & 3,9 & $\mathrm{~N}=427$ & 0,14 \\
\hline \multicolumn{6}{|c|}{ Agglomeráció } \\
\hline Szegény & 38,9 & 61,1 & 0,0 & $\mathrm{~N}=163$ & 0,0 \\
\hline Lakótelep & 6,0 & 83,4 & 10,6 & $\mathrm{~N}=307$ & 1,76 \\
\hline Családi ház & 16,7 & 79,3 & 4,0 & $\mathrm{~N}=1870$ & 0,24 \\
\hline Elit & 4,2 & 85,5 & 10,3 & $\mathrm{~N}=175$ & 2,45 \\
\hline Összesen & 10,5 & 78,3 & 11,3 & $\mathrm{~N}=12923$ & 1,07 \\
\hline
\end{tabular}

* a jómódúak és az elesett csoportba tartozók arányának hányadosa

Forrás: A survey adataiból végzett számítások. 
A fővároson belül - ahogyan korábbi kutatásaink már jelezték - a szegénység felhalmozódásának kockázata elsősorban a város két slumosodó, vagy a slumosodáshoz közelálló övezetének körfolyosós (volt) bérházaiban ${ }^{8}$, elsősorban ezek udvari lakásaiban a leggyakoribb. Az agglomerációban - a kifejezetten szegénységet jelentő övezetek evidenciái mellett - a tradicionális családi házas övezetek azok, ahol a szegénységi kockázat különösen magas, bármely - a fent említett övezeteken kívüli - fövárosi övezet mutatóját meghaladja. A lakóövezet jellege sejteti, hogy ebben az esetben sok vonatkozásban más típusú szegénységi kockázatról kell beszélnünk, mint amikor a főváros belső területeinek slumosodási kérdéseiről gondolkozunk. Az övezetek részletesebb vizsgálatához egy olyan mutatót használunk, mely azt jelzi, hogy a jómódúak súlya hogyan alakul elesettekéhez képest. ${ }^{9}$

Ahogyan az sejthető, a magasabb státuszú lakásokban élők jelentős hányada tartozik a jómódúak közé. Ez azonban nem evidencia. A fơvárosban például három olyan övezet van, ahol ez az arányszám viszonylag nagy ('társasház, villa' - 5,1, 'családi ház 1' - 3,1, 'lakótelep 1'-4,9). Az agglomerációban pedig csak az 'elit' övezet az, ahol az elesettekhez képest magas a jómódúak gyakorisága (két és félszeres), ez valamivel magasabb, mint a fövárosi paneles lakótelepek arányszáma $(2,1)$, de még mindig jóval a főváros három másik területén tapasztalt alatt maradt. Ez a két adat tehát jól jelzi azt a más forrásokból is valószínúsített jelenséget, mely szerint az agglomeráció elit-övezetei, még ha súlyuk az agglomerációs övezetben nem mindenhol egyformán nagy, a föváros környékének hangsúlyozottan homogén magas státusú szegregátumait jelentik. Az elmúlt néhány évben történt változások pedig ezt az övezetet folyamatosan a föváros megfelelő övezeteinek "konkurenseivé" tették. Hasonlóan jól látható az is, hogy az agglomerációs terület legrosszabb lakásállományú része ugyan a legnagyobb arányban jelent az elesettek számára lakóhelyet, viszont ebben az övezetben már megjelent bizonyos számú tehetős lakó is, talán éppen annak első jeleként, hogy ezen területeken is megindul( $\mathrm{t}$ ) a szuburbanizálódásnak az az ága, amely meghatározott körzetek státusemelkedésével jár együtt. Az agglomeráció nagy kiterjedésű családi házas övezete viszont a főváros belső részének legalacsonyabb státusú körzeteivel mutat számottevő hasonlóságot. Így a szegénység területi strukturálódását illetőleg valamelyest világosabb a kép. A fővároson belül nem csak az elesettek népességen belüli arányát tekintve, hanem a jómódúakhoz viszonyított súlyuk szerint is a slumosodó bérházas övezetek főleg udvari lakásainak halmaza az, ahol a szegények szegregálódása a leginkább hangsúlyozott, és ennek megfelel az agglomerációban a családi házas övezet hasonló szinten mozgó adata.

A lakóhelyi státus önálló hatására utal az is, ha megvizsgáljuk, hogy a különböző helyen lakó azonos státusúak között milyen jövedelem különbségek vannak. A jövedelmi adatok használatának korlátai miatt a finomabb eszközök alkalmazásától most kénytelenek voltunk eltekinteni, és csupán azt vizsgáltuk meg, hogy az egyes iskolai végzettségi csoportokon belül a legjobb helyzetü övezetben lakók egy före jutó jövedelme hányszorosa a legszegényebb körzetben lakókénak. 
Adataink azt mutatják, hogy a különbség a középfokú végzettségűek esetében a legalacsonyabb. A legalacsonyabb egy före jutó jövedelemről beszámoló középfokú végzettségü kérdezettek az agglomeráció családi házaiban élnek (a középfokú végzettségü csoport esetében ezek voltak a legrosszabb jövedelmi helyzetben lévők). Ezzel szemben, a fövárosi társasházakban lakók jövedelme, mintegy 40\%-kal magasabb, mint a rosszabb státusú helyen lakóké. A teljesen iskolázatlanok csoportjában (tehát azok között, akiknek legmagasabb iskolai végzettsége nem éri el a nyolc általánost sem) a legalacsonyabb egy före jutó jövedelemmel az agglomeráció szegény övezeteiben élők rendelkeznek, a legmagasabbal pedig a főváros társasházas övezetében lakók. Ebben az esetben a legjobban keresők közel 60\%-kal keresnek többet a legrosszabbul keresőknél. A területi státus hatása legerősebbnek a diplomások esetében mutatkozik. Közöttük a főváros szegény övezeteiben találtuk azokat, akik egy före jutó jövedelmüket a legalacsonyabbra helyezték. Ehhez képest 80\%-kal magasabb az agglomeráció magas státusú övezetiben lakó diplomások által becsült egy före jutó jövedelem.

A társadalmi státus dimenziói és a területi státus között tehát szoros összefüggés van. Ugyanakkor az is megmutatkozik adatainkban, hogy ez utóbbi dimenzió nem minden társadalmi réteg esetében egyforma hatású. A fővárosban és a hozzá csatlakozó területen ebben az első megközelítésben úgy látszik, hogy elsősorban a magas státusúak esetében van erőteljes szerepe a lakóhely területi státusának. Ez nyilván összefügg az utóbbi évek fokozódó szuburbanizálódási tendenciáinak már említett, jellemző mozzanatával, amely a magas státusú - és dinamikusan javuló helyzetü fővárosi csoportok egy részének az agglomerációba költözésében öltött testet. Adatainkból ugyanakkor azt is láthatjuk, hogy az agglomeráció és a főváros is igen erősen strukturált, mindkét területen találunk olyan övezeteket is, amelyeken a szegénység felhalmozódásának jelentős kockázatával is szembe kell nézni.

\section{Az agglomerációban élők kapcsolata Budapesttel}

Budapest és az agglomeráció között mindig létezet kapcsolat. A szocializmus alatt bizonyos értelemben az agglomerációs területek jelentették a fóváros lakástartalékát. Ennek okát a fővárosi munkaerő szükséglet és lakásellátottság (illetve az ezt szabályozó tényezők) sajátosságaiban kell keresni. Budapest dinamikusan fejlődő ipara számára az ország minden részéről ide áramló (áramoltatott) munkaerőnek úgy nyújtottak munkahelyet, hogy közben nem ,gondoskodott” lakóhelyről számukra. A lakhatást, letelepedést szabályozó rendelet ugyanis adminisztratív eszközökkel tartotta távol a vidékről érkezőket, és ezen keresztül próbálta „csökkenteni” a fővárosi lakáshiányt. Így az érkezők ugyan munkához jutottak, de - nagy részük és mint a szocialista lakáselosztás müködési módjából következett, főleg az alacsonyabb státuszú, „kevésbé fontos” részük - lakást csak a környező településeken találhattak maguknak. A hatvanas évektől megszokottá vált az ingázás, ezen keresztül az itt élők szoros kapcsolatban álltak a fővárossal. Ennek viszont az volt az ára, 
hogy a települések egy része alvóváros jelleget kezdett ölteni. A népesség korán reggel elment és csak későn este tért vissza.

A rendszerváltás ebben a tekintetben is változást hozott. A meginduló szuburbanizáció átrendezte a főváros környékén-lakás ok-okozati viszonyait. A „kint lakás” nem annyira kényszerített, mint inkább választott lehetőséggé vált. A magasabb státusúak esetében a kertvárosi lét fizikai és szimbolikus előnyeiért, az alacsonyabb státusúak esetében a könnyebben fenntartható lakásért, és olcsóbb megélhetésért. A korábbi szoros kapcsolat, amely az agglomerációs településeken élők jelentős részét a fövároshoz kötötte, a rendszerváltás után mennyiségi és minőségi értelemben is megváltozott. Hipotézisünk szerint a kilencvenes évek utolsó harmadáig a magasabb státusúak jelentős része még mindig a fővárosban dolgozott, vagyis mind a két lehetőségből a legnagyobb haszonnal kecsegtetőt „szerezte meg” magának (fővárosi munkahely-kertvárosi lakóhely). ${ }^{10} \mathrm{Az}$ alacsonyabb státusúakra viszont inkább volt jellemző a teljes elszakadás. De mit is értünk teljes elszakadás alatt, hiszen a kapcsolatoknak több fajtája létezik. A legszorosabbnak azt tekintjük, ha valaki munkahelyével kötődik a fővároshoz. Ennél lazább, vagy pontosabban, más jellegü viszonyról van szó, ha bevásárlási és kulturális, illetve orvosi ellátásért ,jár fel” Budapestre. Ezért a mindennapi kapcsolatokat ezen mutatók mentén mérve ellenőrizzük hipotézisünket. ${ }^{11}$

\section{TÁBLÁZAT}

A Budapesttel való kapcsolat az agglomerációban lakóknál, iskolai végzettségenként (\%)

(The Relationship with Budapest of the Agglomeration Inhabitants by Educational Qualification, \%)

\begin{tabular}{|c|c|c|c|}
\hline & Van kapcsolat & Nincs kapcsolat & \multirow{2}{*}{$\begin{array}{l}\text { Összesen } \\
\mathrm{N}=100 \%\end{array}$} \\
\hline & \multicolumn{2}{|c|}{$\%$} & \\
\hline 8 általánosnál kevesebb & 18,5 & 81,5 & $\mathrm{~N}=299$ \\
\hline 8 általános & 35,4 & 64,6 & $\mathrm{~N}=679$ \\
\hline Szakmunkásképző & 43,5 & 56,5 & $\mathrm{~N}=674$ \\
\hline Érettségi & 58,5 & 41,5 & $\mathrm{~N}=623$ \\
\hline Föiskola, egyetem & 67,8 & 32,2 & $\mathrm{~N}=281$ \\
\hline Összesen & 45,6 & 54,4 & $\mathrm{~N}=2556$ \\
\hline
\end{tabular}

Forrás: A survey adataiból végzett számítások.

Az agglomerációban lakók közel felének (45,6\%) esetében a fövárosi munkahely és/vagy bizonyos alapvető szolgáltatások fővárosi igénybevétele a lakóhelyként szolgáló települést mintegy főváros 'közelivé' teszi. Feltűnő, hogy a fizikai kapcsolat milyen szorosan kötödik a társadalmi státushoz. A diplomások között közel négyszer annyian vannak olyanok, akiknek mindennapi életében a fövárossal való kapcsolat lényeges szerepet játszik, mint a leginkább iskolázatlan agglomerációs lakók között. A korábbiakhoz hasonlóan, részletesebb adatainkból az is látható, hogy a fenti különbségek - némileg kisebb mértékben - a térbeni dimenzió két közvetlenebb mércéjét használva is megmutatkoznak. Az agglomeráció 'elit' övezeteiben $56,8 \%$ a Budapesttel kapcsolatban lévők aránya, szemben az alacsonyabb 
státusú övezetek valamivel egyharmad feletti arányszámával. De a földrajzi-területi bontásban vizsgált adatok esetében is az a helyzet, hogy míg az északnyugati agglomerációs területen lakók mintegy kétharmada, $(65,3 \%)$, addig a déli övezetben lakók 42,6\%-a és az északkeleti övezetben élők alig több mint egyharmada $(35,4 \%)$ életében jelent a budapesti kapcsolat állandó tényezőt.

A társadalmi státus térbeli dimenziójának müködését világosabbá teheti, ha az agglomeráció és a főváros kapcsolatrendszeréből csak az agglomerációban lakó aktív keresők budapesti munkavállalásának arányait vizsgáljuk meg. Ennek a faktornak a kiemelését nem csupán az teszi indokolttá, hogy hagyományosan is az agglomerációs területek egyik legfontosabb problémájának szokás tekinteni, hanem az is, hogy az utóbbi években a szuburbanizálódási folyamatok jellege valószínüleg megváltozott. Korábban - mint többféle kutatás eredményeiből tudjuk - az agglomerációs lakóhely és fővárosi munkahely kettőssége egyértelmüen azt jelentette, hogy az érintettek kiszorultak a városból a nagyon alacsony státusú lakóövezetekbe, tehát ezekben az esetekben a lakóhelyi területi státus az általános társadalmi státust negatívan befolyásolta. Az utóbbi években viszont egyrészt jelentős mértékủvé vált a magas státusúak kiáramlása az agglomeráció bizonyos körzeteibe, és esetükben a fővárosi munkahely - agglomerációs lakóhely kettősségének már más a jelentése, mint korábban. A magas státusú agglomerációs lakókörzetek létrejötte azt jelenti, hogy most már ezek az övezetek alkalmasak arra, hogy bizonyos rétegek számára az iskolai végzettséggel, munkamegosztási pozícióval elért státust legalábbis megfelelően tükrözzék, illetve szimbolikus értelemben emelni is képesek legyenek. Ugyanakkor ennek a folyamatnak - a kilencvenes évek közepén - még a kezdetén tartottunk, és mint korábban is láttuk, az agglomerációs övezetben megtalálhatóak azok az alacsony státusú lakóövezetek is, ahol a korábban keletkezett hátrányok konzerválódtak, egyebek között abban a tekintetben is, hogy az alacsony státusú fơvárosi munkahely hátrányait tovább erősíti az agglomerációs lakóhely térbelileg meghatározott hátránya. Mindezek miatt a következőkben ezért a fövárossal élő kapcsolatok halmazából a munkahelyet emeljük ki, és az agglomeráció egyes területein belül azt vizsgáljuk, hogy a különböző iskolai végzettségű megkérdezettek között milyen arányban találhatunk olyanokat, akiknek munkahelye Budapesten belül van. Ez a dimenzió újabb oldalról világítja meg az agglomeráció kettősségét. Még jobban elkülöníthetővé válnak egymástól a magasabb és alacsonyabb státuszú területek. Ennek megfelelően egyik oldalon találjuk a főváros magas státuszú övezeteinek térbeli „folytatásaként” létrejött viszonylag dinamikus körzeteket. Másik oldalon pedig a fövárosból kiszorultak körzeteit, és a különböző okokból hagyományosan viszonylag alacsony státuszú lakóhelyeket.

Az északnyugati agglomerációs övezetben az értelmiségiek 43,3\%-a jár Budapestre dolgozni. Ugyanakkor ebben az övezetben az iskolázatlanabbak között ez az arány lényegesen alacsonyabb, jelezve, hogy nem a teljes terület, hanem annak elsősorban a magas státusúak által lakott övezetei azok, ahol az agglomerációs lakóhely a státus emelését jelenti. Az agglomeráció másik két körzetében lakó diplomásoknak csak megközelítőleg egyharmada jár Budapestre dolgozni. Ezek a 
lakóövezetek, mint más adatainkból látható, fizikai jellemzőik, de különösen általában alacsony szimbolikus státusértékük miatt jelenleg az értelmiség magas státusú része számára - akik budapesti foglalkozásukat nem adnák fel a lakásváltozás miatt - még csak kevéssé alkalmasak státusuk „megjelenítésére”, esetleg emelésére.

\section{TÁBLÁZAT}

A Budapesten dolgozók aránya, az agglomeráció egyes területein élö, különbözö iskolai végzettségü csoportok között (\%)

(Share of People Working in Budapest among Groups Living in Certain Areas of the Agglomeration with Different Educational Qualification \%)

\begin{tabular}{lcccc}
\hline & Déli terület & $\begin{array}{c}\text { Északkeleti } \\
\text { terület }\end{array}$ & $\begin{array}{c}\text { Északnyuga- } \\
\text { ti terület }\end{array}$ & Összesen \\
\cline { 2 - 5 } & \multicolumn{4}{c}{$\%$} \\
\hline 8 általánosnál keve- & 24,9 & 100,0 & 0,0 & 34,6 \\
sebb & 17,3 & 56,4 & 0,0 & 21,0 \\
8 általános & 35,2 & 36,7 & 16,2 & 31,5 \\
Szakmunkásképző & 32,7 & 45,1 & 30,7 & 33,9 \\
Érettségi & 36,0 & 31,6 & 43,3 & 38,8 \\
Főiskola, egyetem & 30,9 & 44,7 & 25,8 & 31,6 \\
\hline \hline
\end{tabular}

Forrás: A survey adataiból végzett számítások.

A déli agglomerációs övezet az, ahol az iskolázatlanok között akár két- háromszorosa is lehet a fővárosba ingázók aránya annak, mint amit a magasabb státusú területeken megfigyelhetünk. Ez az adat jól jelzi azt a több más - itt most a rövidség kedvéért nem részletezett - adattal is megerősített - jelenséget, mely szerint az agglomerációnak ez a része az, ahol a tradicionálisan relatíve alacsony státusú lakóösszetétel mellett letelepedtek azok, akik az ország más részeiből érkeztek, akik a szocialista iparpolitika és városfejlesztési politika együttes hatására munkát találtak a fóvárosban, - ha nem is nagyon kvalifikált elfoglaltságokat - miközben letelepedni csak az agglomeráció alulurbanizált vidékein tudtak.

\section{Összefoglalás}

A Budapest és agglomerációja kérdés arra jó példája annak, hogy a politikaihatalmi struktúra megváltozása milyen hatásokkal jár a társadalmi viszonyokra. Mint minden példa annyiban érdekes, amennyiben önmagán túlmutató jelentősége is van. Éppen ezért miközben az empirikus elemzés követelménye, hogy a jelenségeket minél komplexebb módon ragadjuk meg, igen fontos az is, hogy megfogalmazzuk azokat a hipotéziseket, illetve következtetéseket, melyek azt körvonalazzák, hogy a társadalom általunk vizsgált metszete milyen korlátokkal tükrözi az általánosnak tekinthető változásokat. Elemzéseinkből adódó legfontosabb következtetés talán éppen az, hogy a város és környezetének fejlödése egyszerre tükrözi a „spontán” folyamatok és a hatalmi - tervezési beavatkozások következményeit. A spontán folyamatok között példaként megemlíthetjük az általános globalizációs 
hatások jellegzetes részeként a nyugati életmód-minták elérhetőbbé és főleg kívánatosabbá válását. Ez természetesen a társadalomnak elsősorban azon rétege számára jelent valódi kihívást, amelyik egyrészt jobban tájékozott ez ügyben, másrészt anyagi és egyéb tőkékhez való hozzájutási esélyei olyanok, hogy képes lehet ezeket megvalósítani. Az itt nem részletezett mechanizmusokon keresztül életmódmintává váló szuburbánus lét - a nyugati középosztály jól meghatározott részének „normál” életmódja - tehát Közép-Kelet-Európában a rendszerváltás viszonylagos nyerteseivé váló csoportok számára jelent kívánatos és lehetséges követendő életformát. Ugyanakkor az erre irányuló törekvések nem csupán olyan spontán folyamatokat jelentenek, mint hogy megnő a kereslet a megfelelö telkek iránt, egyre inkább az „emberi lakóhely” definíciójává válik a családi házas életforma. A középosztály, de általában a hatalmon lévők azon szokásának megfelelően, hogy saját igényeit és normáit, mint univerzális, mindenkire vonatkozó igényekként, normákként állítsa be. Mindenféle ideológiai „érvek” is születnek és erősödnek amellett, hogy igazolják a szuburbanizálódásra való törekvés indokoltságát. Ezek az érvek számukra annak ellenére bizonyulnak hatékonynak, hogy más vonatkozásban rengeteg racionális ellenérv (lásd pl. utazási idő) éppen e csoportok számára határozottan megkérdőjelezhetné a térbeli mobilitási folyamat célszerüségét. E folyamatok jól mutatják, hogy alapvetően a lakóhely társadalmi státusnak megfelelö megválasztásáról van szó, és ehhez képest tulajdonképpen másodlagos, hogy milyen konkrét elönyöket biztosít, milyen hátrányok árán a választott lakóterület. (Természetesen - hiszen most magas státusú rétegek lakóhelyválasztásairól, költözéseiről beszélünk - a fizikai, környezeti körülményekben is általában elönyösebb helyekre mozdulnak el e csoportok. Az a következtetés, hogy a változás motívuma elsősorban státus megörzés, illetve emelés, természetesen nem jelenti azt, hogy a tárgyi körülmények ne volnának kedvezőbbek, mint az alacsonyabb státusú csoportok lakóhelyeinek esetében.) E spontánnak tekinthetö folyamatok és hatásaik természetesen önmagukban is szorosan kötődnek ahhoz, hogy a kilencvenes évek átalakult hatalmi rendszere és megváltozó gazdasága milyen lehetőségeket biztosít és milyen célokat enged felrajzolni a nyertesek számára. Ugyanakkor a folyamat közelebbröl megvizsgálva nem egyszerüen spontán törekvésekből és ezekre adott kényszerủ válaszokból áll, hanem ugyanebbe az irányba ható jól meghatározott hatalmi és tervezői környezetben zajlik. Elég itt azokra a csatározásokra utalni, amelyek a főváros politikai vezetése és a központi kormányzat között zajlottak, és amelyek következtében a föváros és környezete gazdasági és társadalmi problémáinak szintetikus kezelése a mai napig többé-kevésbé lehetetlenné vált. Ugyanígy azok a döntések, amelyek az önkormányzatok gazdálkodását meghatározzák egyenes következményekkel járnak arra nézve, hogy ezen települési önkormányzatok milyen mértékben ösztönzik és milyen mértékben állnak ellent a beköltözőknek, hogyan és milyen mértékben igyekszenek területük egy részét ipari és kereskedelmi és szolgáltatási célokra értékesíteni, stb. Ráadásul e településfejlesztési és településrendezési döntések jól meghatározott tervezési folyamatok keretei között zajlanak. E folyamatok a döntéshozatali rendszer újabb szereplöit, magukat a tervezőket is képbe hozzák, saját többé-kevésbé 
elkülönült érdekeikkel, érdekérvényesítési küzdelmeikkel. Így tehát az érdekeltek spontán törekvései mellett a szakértői és politikai döntések bonyolult rendszere alapvetően meghatározza azokat a feltételeket, azokat az irányokat, amelyek között spontán törekvések érvényesülni képesek. A kilencvenes évek Közép-KeletEurópájának valószínűleg egyik legfontosabb kérdése éppen az, hogy az átalakuló hatalmi érdekviszonyok között a különböző társadalmi csoportok milyen mértékben és milyen mechanizmusokon keresztül képesek arra, hogy érdekeiket érvényesítsék, s e bonyolult rendszerben mennyire figyelhetünk meg a nyugat-európai modellekhez hasonló folyamatokat, és mennyiben tekinthetjük sajátos közép-kelet-európai mechanizmusnak a megfigyelt folyamatokat. Így tehát a főváros és agglomerációja kapcsán bemutatott szuburbanizációs folyamtok azok a társadalmi konfliktusok és kockázatok, amelyeket megfigyeltünk elsősorban éppen annak példájaként szolgálnak, hogy a rendszerváltás első tíz-tizenkét éve e téren milyen sajátosságokat mutatott.

\section{Jegyzetek}

${ }^{1}$ A tanulmány az OTKA T032332 számú kutatása keretében készült.

${ }^{2}$ A legfontosabb kivételt - az RKK esettanulmányaitól eltekintve - a Kovács Zoltán és Dövényi Zoltán empirikus kutatása jelentette.

${ }^{3}$ Ebben a tanulmányban - terjedelmi okokból - nem foglalkozunk a folyamat másik részével. Azzal, hogy milyen társadalmi csoportok költöznek be a fövárosba, és ezek honnan érkeznek és a főváros mely részei felé tartanak.

${ }^{4}$ A surveyt 1996-97 folyamán négy hullámban a Sonda-Ipsos bonyolította le. Megyei reprezentatív mintákból összesúlyozott országos reprezentatív minta készült. A nagy minta lehetőséget adott arra, hogy elemezhető méretủ almintát kapjunk azokról, akik 1990 óta költöztek jelenlegi lakóhelyükre.

5 A mutatót három elemböl építettük fel. Egyrészt figyelembe vettük, hogy megkérdezettjeink rendelkeznek-e saját lakásukon kívül más ingatlannal, ingó vagyonnal. A magas státus jelzésére szolgált az is, ha a megkérdezett a tartós fogyasztási cikkek bizonyos státus-jelző szereppel is bíró darabjait birtokolta. A másik oldalon, az elesettség kockázatának jelzésére használtuk, ha a kérdőívben felsorolt tartós fogyasztási cikkek között csak a korszerütlen állt rendelkezésre (pl. csak fekete-fehér TV, csak hagyományos mosógép). Ezen túl csak abban az esetben tekintettünk elesettnek valakit, ha a korábban említett magas státust jelző vagyontárgyak és tartós fogyasztási cikkek nem voltak birtokukban, és egyúttal az is előfordult, hogy a családban pénzhiány miatt ennivalóra, fütésre, vagy lakbérre nem futotta. A kedvező anyagi helyzetủ csoport kialakításánál tehát úgy jártunk el, hogy jómódúnak azokat tekintettük, akiknek egyaránt volt vagyonuk, rendelkeztek a magas státust jelző tartós fogyasztási cikkek legalább egyikével, és az elmúlt évben nem fordult elő anyagi krízishelyzet családjukban.

${ }^{6}$ A fővárosi népesség térbeli helyzetét jellemző státus-változót oly módon hoztuk létre, hogy a várost viszonylag kicsi, aránylag homogén területegységekre bontottuk, majd az ezekre jellemző statisztikai adatok sokdimenziós elemzése (ún. cluster-analízise) segítségével városszociológiailag is jól értelmezhető aggregált területeket, clustereket hoztunk létre. Ez után a minta térbeli eloszlását a megfelelő számítógépes térképezési eljárások alkalmazásával megfeleltettük a cluster-analízis eredményeként kapott területi rendszernek. Az így létrehozott klasszifikációban a megkérdezettek lakóhelyi-területi státusának az egyik összetevője az, hogy a városnak melyik részén, milyen státusú területén (clusterében) laknak. A mintánk különböző dimenzióiban megfigyelhető szóródások jól értelmezhetöek e szerint a területi rendszer szerint.

Ezen túlmenően a kérdőíves vizsgálat adta lehetőségekkel élve még arra is módunk volt, hogy a megkérdezettek területi státusát az eddigieknél még pontosabban mérjük. Ehhez a lakóház városszerkezeti helyét kiegészítettük a lakóház jellegét mutató dimenzióval. Végeredményben e két dimenzió együttes elemzése alapján hoztuk létre a fővárosi megkérdezettek területi státusát mutató - az adott vizsgálat méreteihez alkalmazkodó - tíz kategóriás változót. Ennek segítségével most már nem csak arra van lehetőségünk, hogy az igazán magas, illetve alacsony státusú övezeteket különítsük el egymástól, hanem arra is, hogy megvizsgáljuk, hogy a különböző státusú családi házas környékek, a különbözö stá- 
tusú lakótelepek, illetve az eltérő jellegzetességeket mutató bérházas övezetek milyen mértékben jelentenek eltérő társadalmi-térbeli státusokat is. Az új dimenzió adta lehetőségeket pedig elsősorban a szegénység térbeli koncentrálódás-kockázatainak vizsgálatára használtuk fel, úgy a 'kemény’ tény-adatok, mint az ezekkel szorosan összefüggő attitüdök, aspirációk vonatkozásában.

${ }^{7}$ Mobilitáson itt most egyszerüen azt értjük, hogy megkérdezettjeink és édesapjuk iskolai végzettséggel mért társadalmi státusa milyen mértékben tér el egymástól. Ez az eljárás (is) számottevő korlátokkal jár, hiszen a képet igen jelentősen befolyásoló tényezők közül számosat nem tudunk kontrollálni. Az alacsony esetszámok miatt pl. nem standardizálhatunk, az apai generáció kor-struktúrájára, pedig közismerten más társadalmi státust jelez egy adott iskolai végzettség aszerint, hogy mikor is élt annak megszerzője. Hasonló okokból nem tehetünk különbséget különbözö mobilitási típusok között sem, bár világos az is, hogy nem egyforma nagyságú lépcsőket kell magunk elé képzelni akkor, ha az egyes iskolai végzettségi szintek közötti társadalmi távolságokat próbáljuk képletessé tenni. E korlátok azonban a megfelelő óvatosság mellett nem teszik értelmezhetetlenné azt a különbséget, ami azok között figyelhető meg, akik az előző generáció státusát megőrizték, és azok között, akik ahhoz képest magasabb, illetve alacsonyabb helyzetüek.

${ }^{8}$ bérház2 és bérház3, szükség és egyéb lakás

${ }^{9}$ Bizonyos értelemben a két csoport egymáshoz viszonyított nagysága az adott terület státusának mérőszámaként is felfogható, feltéve, hogy - mint esetünkben általában - nem túlzottan kicsi a két vizsgált csoport együttes súlya az össznépességen belül. A területegységek összehasonlításához az is szükséges, hogy az össznépességen belüli együttes arány ne is legyen túlzottan eltérő az egyes vizsgált területek között.

${ }^{10}$ Meg kell jegyeznünk, hogy újabb kutatásaink szerint - melyeket azonban empirikus adatokkal még nem tudunk eléggé alátámasztani - a magas státuszúak egy része a kilencvenes évek legvégén teljesen „agglomerálódott”, vagyis feladta fővárosi munkahelyét és „helyben” fogott vállalkozásba, vagy talált másik munkahelyet magának.

${ }^{11}$ Az adatok úgy keletkeztek, hogy megkérdezettjeink kilenc dimenzióban nyilatkoztak arról, hogy bizonyos alapvető szolgáltatásokat (a szakorvostól a gyerekek iskoláztatásáig, illetve a szórakozástól a vásárlásig) saját településükön, vagy máshol vesznek igénybe, illetve tizedik, sok szempontból kiemelt dimenzióként a munkahely területi elhelyezkedéséröl szereztünk információkat. Ha ezek között a megjelölt területek között szerepelt a főváros, akkor az illető megkérdezettet olyannak tekintettük, akinek van mindennapi kapcsolata Budapesttel. Természetesen nem ugyanazt jelenti, ha ez a kapcsolat ruhavásárlásban merül ki, mint ha a kérdezett területek többségében a föváros szolgál az igények kielégítéséhez. Mostani vizsgálatunk esetszáma és egyéb korlátai azonban nem teszik lehetővé azt, hogy ezekre a finomabb eltérésekre is kitérjünk.

\section{Irodalom}

Beluszky P. (1999) A budapesti agglomeráció kialakulása - Barta Gy.-Beluszky P. (szerk.) Társadalmigazdasági átalakulás a Budapesti agglomerációban MTA RKK,. Budapest.

Castells, M. (1979) The Urban Question. MIT Press, Cambridge:

Csanádi G.-Ladányi J. (1992) Budapest térbeni-társadalmi szerkezetének változásai. Akadémiai Kiadó, Budapest.

Daróczi E. (1999) Ki a fővárosból-változások Budapest és az ország vándorforgalmában - Barta Gy.Beluszky P. (szerk.) Társadalmi-gazdasági átalakulás a Budapesti agglomerációban MTA RKK, Budapest.

Dövényi.Z.-Kok.H.-Kovács Z. (1998) A szuburbanizáció, a lokális társadalom és a helyi önkormányzati politika összefüggései a budapesti agglomerációban. - Illés.S.-Tóth P.P. (szerk) Migráció I. KSH Népességtudományi Kutató Intézet, Budapest. 229-237. o.

Dövényi Z.-Kovács Z. (1999) A szuburbanizáció térbeni-társadalmi jellemzői Budapest környékén. Földrajzi Értesitö. 1-2.33-57. o

Enyedi Gy. (1996) Regionális folyamatok Magyarországon. Hilscher Rezsõ Szociálpolitikai Egyesület, Budapest.

Kovács K. (1999) A szuburbanizációs folyamatok a fővárosban és a Budapesti agglomerációban. - Barta Gy.-Beluszky P. (szerk.) Társadalmi-gazdasági átalakulás a Budapesti agglomerációban MTA RKK,. Budapest.

KSH (1998) A budapesti agglomeráció az ezredforduló küszöbén Közlemények a budapesti agglomerációról 8. KSH, Budapest. 
Ladányi J.-Szelényi I. (1997a) Szuburbanizáció és gettósodás - Szociális, etnikai és térszerkezeti változások az ezredforduló Magyarországán és Budapestjén. - Kritika. 6. 4-12. o.

Ladányi J.-Szelényi I. (1997b) A társadalom etnikai-, osztály- és térszerkezetének összefüggései az ezredforduló Budapestjén - Kárpáti Z. (szerk.) Társadalmi és területi folyamatok az 1990-es évek Magyarországán. MTA TKKK, Budapest.

Perger É. (1999) Közigazgatási dilemmák. - Barta Gy.-Beluszky P. (szerk.) Társadalmi-gazdasági átalakulás a Budapesti agglomerációban MTA RKK, Budapest.

Szelényi I. (1990) Városi társadalmi egyenlötlenségek (Tanulmányok). Akadémiai Kiadó, Budapest.

Szelényi I. (1996) Cities under Socialism- and After. - Andrusz, G.-Harloe, M.-Szelényi, I. (szerk.) Cities after Socialism. Blackwell, Oxford.

Tímár J.(1999) Elméleti kérdések a szuburbanizációról. - Földrajzi Értesítő. 1-2. 7-31. o.

Tosics I. e.a. (1998) Szuburbanizációs tendenciák és településfejlesztési stratégiák Budapesten és agglomerációjában. Kézirat. Városkutatás Kft., Budapest.

Tomay K. (2002) Migrációs folyamatok Budapesten és környékén a kilencvenes években. Kézirat. Szakdolgozat.

Váradi M. (1999) Hová megyünk lakni? Szuburbanizációs minták és konfliktusok a budapesti agglomeráció budai oldalán. - Barta Gy.-Beluszky P. (szerk.) Társadalmi-gazdasági átalakulás a Budapesti agglomerációban MTA RKK,. Budapest.

Weslawowicz, G. (1992) A városok térbeni-társadalmi szerkezete kelet-közép Európában. - Tér és Társadalom. 6. 3-4. 215-225. o.

\section{SUBURBANISATION AND SOCIETY}

\section{GÁBOR CSANÁDI - ADRIENNE CSIZMADY}

The situation of Budapest and its agglomeration is a good example how the change of the political-power structure effects social relationships. In the last few years between the two fields more closer connection and interaction was developed than earlier. These changes make it reasonable to analyse how can we understand the spatial dimension of urban society, when we carry out our survey not simple within the administration border of the capital, but we examine both the capital and its agglomeration. The first question of the study is how can we understand the spatial dimensions of social processes within the area of the capital and its agglomeration. In other words we analyse that the spatial segregation of high and low status strata in what extent step across the settlement borders and what kind of patterns do the risks of the poverty concentration have during such research. 